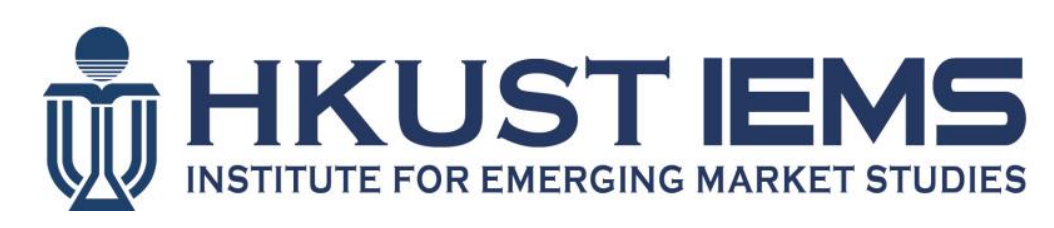

\title{
Fiscal Incentives and Policy Choices of Local Governments: Evidence from China
}

\author{
Li HAN, James Kai-Sing KUNG
}

HKUST IEMS Working Paper No. 2015-13

March 2015

\begin{abstract}
HKUST IEMS working papers are distributed for discussion and comment purposes. The views expressed in these papers are those of the authors and do not necessarily represent the views of HKUST IEMS.
\end{abstract}

More HKUST IEMS working papers are available at: http://iems.ust.hk/WP 


\title{
Fiscal Incentives and Policy Choices of Local Governments, Evidence from China
}

Li HAN, James Kai-Sing KUNG

HKUST IEMS Working Paper No. 2015-13

March 2015

\begin{abstract}
This paper examines how fiscal incentives affect the policy choices of local governments in the context of China. Based on exogenous changes in the intergovernmental revenuesharing scheme, we construct a simulated instrumental variable to resolve the endogeneity problem. We find evidence that local governments shifted their efforts from fostering industrial growth to "urbanizing" China, i.e., to developing the real estate and construction sectors, when their retention rate of enterprise tax revenue was reduced. The increase from the new revenue source compensated for half of the losses in revenue that resulted from the reassignment of fiscal rights. The reassignment had also the effect of retarding the industrial growth of domestically-owned firms in particular.
\end{abstract}

\section{Author's contact information}

Li Han

Division of Social Science

The Hong Kong University of Science and Technology

E: lihan@ust.hk

James Kai-Sing Kung

Division of Social Science

The Hong Kong University of Science and Technology

E: sojk@ust.hk 


\title{
Fiscal Incentives and Policy Choices of Local Governments: Evidence from China
}

\author{
Li Han, James Kai-Sing Kung ${ }^{\dagger}$
}

January 13, 2015

\begin{abstract}
This paper examines how fiscal incentives affect the policy choices of local governments in the context of China. Based on exogenous changes in the intergovernmental revenue-sharing scheme, we construct a simulated instrumental variable to resolve the endogeneity problem. We find evidence that local governments shifted their efforts from fostering industrial growth to "urbanizing" China, i.e., to developing the real estate and construction sectors, when their retention rate of enterprise tax revenue was reduced. The increase from the new revenue source compensated for half of the losses in revenue that resulted from the reassignment of fiscal rights. The reassignment had also the effect of retarding the industrial growth of domestically-owned firms in particular. (JEL: H77, H70, H39)
\end{abstract}

Keywords: Fiscal Federalism, Fiscal Incentives, Revenue Sharing, Local Governments, Land Conveyance, Urbanization, Simulated Instrumental Variable.

*Email: lihan@ust.hk. Division of Social Science, The Hong Kong University of Science and Technology.

†Email: sojk@ust.hk. Division of Social Science, The Hong Kong University of Science and Technology. We thank Roger Gordon, Michelle White, James Poterba, Satoru Shimokawa, Yan Shen, and various participants at HKUST, SWUFE, PKU workshops and the Public Finance Issues in China Conference (2011) for helpful comments, Feizhou Zhou for providing the data on land sales, Xiulin Sun and Shuo Chen for their excellent research assistance, and a research grant from the Chiang Ching-kuo Foundation (grant no.: CCK08/09.HSS02). 


\section{Introduction}

Fiscal decentralization has been a clear trend around the developing world over the past three decades. A large literature has been devoted to understanding its impacts on economic development. Fiscal arrangements that allow local governments to capture a larger proportion of local revenue are often correlated with faster economic growth. ${ }^{1}$ However, the theoretical underpinnings for the decentralization-development nexus remain unclear (see a review by Martinez-Vazquez and McNab, 2003). Some scholars have noted that the fiscal incentives of local governments directly influence their policy choices and hence economic performance in their jurisdiction (Rodden, 2003; Singh and Srinivasan, 2006; Careaga and Weingast, 2003; Weingast, 2009). However, most existing studies have focused on the relationship between fiscal decentralization and economic performance; few have rigorously examined the role of fiscal incentives in shaping the policy choices of local governments. By exploiting exogenous changes in intergovernmental fiscal-sharing schemes in China, this paper attempts to examine how changes in fiscal arrangements affect policy choices and hence the development focus of local governments.

China is the right place to test this fiscal incentives hypothesis. Fiscal decentralization is often considered a key driving force of China's economic miracle in the post-Mao era (see the review by Xu (2011) and the dispute by Cai and Treisman (2006)). An explanation behind this causal link is that decentralization entitles local governments to a large proportion of the new revenue generated by economic growth, and hence creates direct incentives for them to foster local economic prosperity. Some studies have documented qualitative or suggestive evidence that local governments' policy choices responded to changes in the central-local fiscal sharing rules (e.g., Oi, 1992, 1999; Jin et al., 2005; Wang, 2010; Kung, Xu and Zhou, 2013). Notably, local governments shifted their effort in fostering industrial growth to "urbanizing" their locality when the central government halved the local retention rates of enterprise tax revenues and made local

\footnotetext{
${ }^{1}$ For example, Jin et al. (2005) found that provinces in post-reform China retained a large proportion of tax revenue during the high growth period from 1981 to 1992. In contrast, Mexican states were observed to have both much lower retention rate of tax revenue and slow economic growth from 19801995 (Careaga and Weingast, 2003). Similar patterns were also found in Indian states from 1950-1990 (Rao and Singh, 2005), and Russian cities and regions in the 1990s (Blanchard and Shleifer, 2000; Zhuravskaya, 2000).
} 
governments rely on business tax, the bulk of which was obtained from the construction and real estate sectors, and more importantly, on non-budgetary revenue from selling the usufruct rights of land (Kung, Xu and Zhou, 2013). ${ }^{2}$

This paper studies local government policy choices between industrialization (promoting industrial growth) and urbanization (converting arable land for residential and commercial usage) in China. We use the areas and revenues of land conveyance to measure the efforts of local governments to promote urbanization. A new land conversion dataset for the period 1999-2005 is created for this purpose. We use the local industrial growth rate to measure the efforts of local governments to promote industrialization.

A major challenge in identifying the responses of local governments to reduced fiscal revenue is that fiscal revenue is endogenous, as a number of unobserved dimensions may simultaneously affect the outcome variables. For example, to the extent that the more industrialized regions are more likely to enjoy a favorable business environment than their less industrialized counterparts, the former would experience faster growth rates independent of changes in fiscal revenue-sharing rules. More generally, the unobserved year-over-year changes in local circumstances may affect both locally retained tax revenues and local governments' behavior. While we may exploit changes in the tax-sharing scheme to provide an exogenous source of revenue variation for examining local governments' responses, there may still be concerns that local governments may respond to such changes by adjusting their behavior in other ways. For example, they may switch their efforts to exploiting alternative revenue sources in order to compensate for the losses that result from changes in the new tax-sharing schemes. In other words, if the change in the tax-sharing rules results in an endogenous change in the pre-tax-sharing revenue, we cannot directly exploit the changes in the locally retained fiscal revenue as an exogenous source of variation.

To deal with these potential problems, we employ the simulated instrumental variable

\footnotetext{
${ }^{2}$ In theory all land is owned by the state in China. Local governments are authorized to sell the usufruct rights of land for a certain period (up to 70 years) in what the Chinese calls the "primary land market" (yiji tudi shichang). A usufruct right of land can be legally transferred (tudi zhuanrang) within the leasing period in the "secondary market". Ho and Lin (2003) use the terms land conveyance (tudi churang) and land transfer (tudi zhuanrang) to refer to the two types of transactions. For convenience, we will follow this usage throughout the paper.
} 
(SIV) strategy developed by Gruber and Saez (2002) and Dahl and Lochner (2012). SIV is often used to estimate an individual's or a household's response to changes in tax policies. To the best of our knowledge, we are the first to use this method to quantify the responses of local governments to fiscal incentives. SIV allows us to compute the predicted changes in the retained fiscal revenue of local governments. ${ }^{3}$ These changes, which are uncorrelated with other sources of change in the pre-sharing fiscal revenue, allow us to examine the elasticity of land sales to taxation. Our SIV estimates are indeed consistent with the fiscal incentives hypothesis. They show, first of all, that if locally retained fiscal revenue decreased by $1 \%$ (resulting from the reassignment of a substantial part of the enterprise tax to the central government), the area of land conveyed by local governments increased by $6.4 \%-11.0 \%$, and the revenue generated from land conveyance increased by a larger $10.0 \%-16.3 \%$, which could compensate for more than half of the loss of local tax revenues resulted from the changes in the tax-sharing scheme. All these SIV estimates are statistically significant at the $5 \%$ level. On the other hand, OLS estimates of fiscal incentive impacts, which are subject to the endogeneity problem, are either statistically insignificant or positive.

A question arises as to whether the results obtained are driven by the accelerating demand for land. To answer this question, we apply the same SIV strategy to examining land transfers in the secondary land market, which should be more of a response to local demand for land than local fiscal incentives. We are unable to obtain results comparable with those for the primary market for either the area or revenue involved. This lends further credence to our hypothesis that increases in land conveyance by local governments were driven primarily by the reconfiguration of the tax-sharing rules.

Moreover, despite sustained increases in industrial output, we find that changes in fiscal incentives tended to reduce the growth rate of industrial output of particularly domestically-owned firms. Evidence also shows that government expenditures on infrastructure construction increased in response to changes in fiscal incentives. This lends support to the speculation that changes in fiscal incentives had led the local governments to shift their development focus from industrializing to urbanizing their localities.

\footnotetext{
${ }^{3}$ By fiscal revenue, we refer to the sum of the budgetary and extrabudgetary revenues composed mainly of tax revenue and revenue from administrative services. It does not include off-budget funds, to which land conveyance revenues belong. See Section 3 for details.
} 
Taken together, our results show that fiscal incentives had a strong influence on local policy choices. This differs from a more popular approach which emphasizes the political incentives of local officials behind China's economic miracle, namely, the central government spurs local officials to maximize a well-specified target such as GDP growth or revenue remitted to the central government by creating or inducing what is known as "yardstick competition" among local officials (see Xu (2011) for a detailed discussion of this approach). The fiscal incentives approach provides a better explanation for problems in the development process that cannot be explained by the political incentives approach. In particular, it explains local governments' craze for converting land for nonagricultural use in spite of prohibitions from the central government, which was at the expense of industrial growth. This finding implies that the growth path highly depends on the fiscal incentives of local governments in China. Given that China has become the world's manufacturing center, this change has important global implications. Moreover, the housing bubble in China has aroused much international attention particularly after the recent financial crisis. The finding in this paper provides evidence that the rocketing housing price and rapid real estate development can be partly explained by the craze for urbanization of the revenue-hungry local governments. Our finding also sheds light on the design of fiscal arrangements in other countries. Local governments have played an increasingly important role in fostering economic development across the developing world (Bardhan and Mookherjee, 2006). In many countries they can serve either as an engine or obstacle of growth. For instance, Singh and Srinivasan (2006) point out that differences in fiscal arrangements may in fact drive the observed differences in behavior between China's and India's local governments. Careaga and Weingast (2003) provide suggestive evidence that the share of locally generated revenue in the total budget bears importantly upon local governments' incentive to promote economic development in Mexico. However, no previous studies have explicitly and rigorously tested the fiscal incentive hypothesis. Our paper contributes to this literature by providing rigorous evidence that the fiscal revenue generation process is a key determinant of local officials' policy choices.

This paper proceeds as follows. Section 2 reviews the pertinent literature, whereas Section 3 provides the background information on China's fiscal system and local government behaviors. Section 4 describes our data and defines the variables employed in the empirical analysis. Section 5 introduces our empirical model and identification strategy. Estimated effects of changes in fiscal revenue on the land market and industrial output 
are reported and discussed in Section 6. Section 7 concludes the study.

\section{Literature Review}

The economics literature has shown an increasing interest in fiscal decentralization as an engine of economic growth in both developing and developed countries (e.g., MartinezVazquez and McNab, 2003; Akai and Sakata, 2002; Iimi, 2005; Thornton, 2007). However, recent empirical findings on the relationship between decentralization and development are inconclusive. The outcomes of fiscal decentralization are found to depend on the role of local governments (Bardhan and Mookherjee, 2006). The mechanisms through which decentralization may generate different impacts on economic development remain unclear.

Some scholars attribute the difference in the outcomes of decentralization to differences in local officials' political incentives. In particular, following Riker's hypothesis (Riker, 1964), a group of researchers emphasize the importance of political centralization to making fiscal federalism beneficial; that is, in a politically centralized institution, the national government may use political incentives such as promotions and retentions to make local governments respond to local needs as well as aligning their interest with that of the national population (e.g., Enikolopov and Zhuravskaya, 2007). China is an often-cited example for this argument. It is believed that the willingness of the Chinese central government to reward and punish local officials based on the outcomes of regional economic growth has powerfully motivated these officials to adopt pro-business policies (Blanchard and Shleifer, 2001; Maskin, Qian and Xu, 2000; Qian and Xu, 1993; Li and Zhou, 2005; Xu, 2011). However, this tournament-like incentive can hardly account for many of the behaviors of local officials, which are classified by some as externalities of regional competition $(\mathrm{Xu}, 2011)$. An example is their craze for converting arable land for urban use regardless of strict regulations and potential penalty imposed by the central government.

Another principal explanation instead emphasizes the direct impact of fiscal incentives (Weingast, 2009). Investigations of a few developing countries suggest that economic growth tends to be faster where local governments enjoy higher retention rates of rev- 
enue generated in their jurisdiction. In the case of China, fiscal decentralization in the 1980s has made the incentives analogous to those of a linear contract, whereby the "tenant" or agent is entitled to retain and control the "residuals" from that part of the fiscal revenues over and above the agreed-upon contractual amount. This applies to the amount agreed-upon between the central and provincial governments, and accordingly between each successive layer of government below the province level. Some researchers argue that these fiscal incentives induced local officials to foster economic prosperity (Oi, 1992, 1999; Montinola et al., 1995; Qian and Weingast, 1997; Weingast, 1995; Mckin-

non, 1997). In contrast, the lack of fiscal incentives in Russia explains in part why local governments prey on private businesses (Zhuravskaya, 2000). This fiscal incentives explanation is also consistent with findings in other federal countries like Germany, Australia and Mexico (Smart, 1998; Dahlby, 2002; Baretti, Huber and Lichtblau, 2000; Buettner, 2006). However, few studies have rigorously examined in detail how local policy choices, and hence the paths of economic development, are affected by fiscal incentives, not to mention estimating the magnitude of their potential effects.

\section{China's Fiscal Revenue-Sharing Systems and Lo- cal Government Behavior}

The Chinese administrative structure consists of five layers: (from top to bottom) the central, provincial, prefectural, county and township governments. In the remaining part of this section, local governments are broadly referred to the subnational governments from the provincial all the way down to the township level. The way the fiscal revenuesharing system works is that for each and every source of the fiscal revenue the central government stipulates a sharing rule with the provincial government. The provincial government then divides the retained revenue with the prefectural government, which in turn gives a proportion of that to the lower-level governments, and so forth. As subnational governments (in particular, the prefectural and county governments) are responsible for providing public goods such as infrastructure, public education, health care, pension and so on in their jurisdictions, they play an important role in formulating and implementing local economic policies. In particular, given their promotional prospects depend crucially on local economic growth ( $\mathrm{Li}$ and Zhou, 2005), local officials have strong incentives to 
boost local investments using the resources under their control. Their choice of which revenue bases to cultivate thus affects the local economic structure and performance.

The fiscal revenue of local governments can be divided broadly into two categories: budgetary and extrabudgetary revenue. Composed mainly of three tax categories, viz. value-added tax, enterprise tax, and business tax, the budgetary revenue is shared between the local governments and upper level authorities that supervise them. From 1990 onwards the use of budgetary revenue has been subject to regulatory mandates. ${ }^{4}$ The extrabudgetary revenue includes a variety of non-tax items - mostly fees and funds authorized by various governmental departments. ${ }^{5}$ As the local governments are given exclusive authority over the disposal of extrabudgetary revenues, this type of revenue is considered more flexible (Wong, 2007). Moreover, as the central government increases its share of tax revenues, which results in falling revenues for all the levels of local governments, local governments have become increasingly dependent on extrabudgetary revenues for achieving its policy goals (Wong and Bird, 2008).

In addition to these two categories, many local governments have a third source of revenue. Known under a variety of names (extra-extra-budgetary funds, off-budget funds, or extra-system funds), a unique feature of this revenue is that it represents an income source over which the local governments have exclusive claims; oftentimes they are not even required to report them to the central government (Wong and Bird, 2008). A good case in point is land conveyance fees - a revenue stream that local governments are entitled to received from selling the land usufruct rights of formerly arable land to a third party for a different (e.g., urban) usage (tudi churang jin in Chinese). ${ }^{6}$ While this third revenue category has previously been treated as part of the fiscal revenue by some researchers (e.g., Oi, 1999; Wong, 2007), for the sake of conceptual clarity we distinguish this off-budgetary item from the two aforementioned revenue categories.

\footnotetext{
${ }^{4}$ For example, the National Education Law mandated that by 2000 four percent of GDP has to be spent on education which is mainly financed through local governments' budgetary revenue. Likewise, the Agricultural Law requires that budgetary spending on agriculture has to grow at a faster rate than the rate of growth in budgetary revenues.

${ }^{5}$ The extrabudgetary revenue includes various fees and surcharges levied on household utility bills, hospitals and schools, road maintenance, advertisement, vehicle purchases, and so on.

${ }^{6}$ From 2007 on, a proportion of the tudi churang jin has to be included in the budgetary revenue. But since we focus on the period 1999-2005, this change does not affect our analysis.
} 
By fiscal revenue we refer to the sum of the budgetary and extrabudgetary revenue throughout the paper.

Popularly referred to as "federalism, Chinese style", China's fiscal system has undergone two major reforms since the early 1980s; and local governments' policy choices have been seen to reflect these changes. Under the fiscal contracting system (caizheng baogan) implemented around the mid-1980s, local governments were assigned the residual income rights over the surplus of that part of the revenues generated within their own jurisdictions - the bulk of which came from the enterprises they managed. ${ }^{7}$ However, as such revenues drew heavily on the value-added tax instead of profit tax - taxes levied upon transactions incurred in the production process, local governments were more eager to expand the operations of township-and-village enterprises (TVEs) than to concern themselves with their efficiency and accordingly profits (Oi, 1999; Kung and Lin, 2007).

While this fiscal contracting scheme had incentivized local governments to maximize revenues, its design, which allowed local governments to appropriate the value-added tax in full, rendered the central government unable to benefit from this growth process. Concerned with the division of fiscal revenues with the local governments, the central government redefined tax rights in 1994. Specifically, it reassigned to itself $75 \%$ of the transaction or value-added tax, which, as seen earlier was generated mainly from TVEs and other industrial enterprises. This reassignment had allegedly weakened the incentives of local governments in supporting the expansion of enterprises ever since (Kung and Lin, 2007; Li and Rozelle, 2003, 2004). In order not to stifle the incentives of local governments to continue with their developmental efforts, local governments have been assigned exclusive rights over the enterprise tax since 1994 (qiye suode shui), which is drawn upon profits instead of transactions, and the business tax (yingye shui), which is based largely on the construction and to a lesser extent the service sectors. These shifts in revenue rights have allegedly changed the behavior of local governments from simply expanding TVE growth to paying greater attention to corporate efficiency - a change that helps to account for the massive privatization of TVEs towards the end of the 1990s according to some (Kung and Lin, 2007; Li and Rozelle, 2003, 2004).

\footnotetext{
${ }^{7}$ According to Oi (1999), the terms of the contracts vary across places. It could be a lump-sum or fixed-ratio contract. Jin, Qian and Weingast (2005) find that ex ante contracts differed little from the ex post central-local revenue share.
} 
However, the decisive change in the behavior of local governments would not have come about if not for a major statutory legislation enacted in 1998 whereby they were assigned the exclusive rights over revenues generated from selling the usufruct rights of formerly arable land (land conveyance). ${ }^{8}$ Subject only to quota constraints, the prefectural and county governments effectively become a monopolist in the land conveyance market (also known as the primary land market). The former makes the zoning plans, approves the plans of land use proposed by, and shares the land conveyance revenue with, the latter. Since these revenues (tudi churang jin, or land conveyance fees) do not form part of the budgetary revenues subjected to the sharing negotiations between central and local governments, they are not regulated. In this sense, local governments are able to dispense them in manners as they see fit.

It becomes evident that, from early 2000 onwards subprovincial governments in China have increasingly relied upon land conveyance fees as a major source of revenue. But it must be pointed out that the revenues generated from land conveyance did not become a significant revenue source for local governments until 2002, when the central government started reclaiming up to half of the enterprise tax from them (and which was increased to $60 \%$ from 2003 onwards) - a move that significantly reduced the prefectural governments' share of this particular revenue (from approximately $100 \%$ before 2002 to a mere $25 \%-40 \%$ after 2003), and which forced them to go after alternative revenue sources to fulfill their public finance obligations and other self-interested purposes. Land conveyance revenue became an obvious option, and so the local governments started shifting their focus from industrialization to urbanization (in terms of real estate development and construction). The effort to "urbanize" China has had the inadvertent effect of increasing also the business tax (now an important part of the budgetary revenue) and various surcharges levied primarily on the construction and the real estate sectors (as part and parcel of the extra-budgetary revenue) (Kung, Xu and Zhou, 2013). Available evidence suggests that, in the more developed coastal regions, land conveyance revenues obtained from these sources combined have become a major source, or $60-80 \%$, of the local governments' total revenue (Zhou, 2007). The rapid pace by which China has "urbanized" in the years that followed the legislative change in 1998 bears out the underlying importance of not only this statutory change but also the new fiscal incentive. ${ }^{9}$

\footnotetext{
${ }^{8}$ The 15th National Congress of the Communist Party in China, 1997; Xu, 2011.

${ }^{9}$ Typically, China is considered "under-urbanized" because of the hukou system, as it restricts rural-
} 
Figure 1 summarizes the changes in the central-local sharing scheme of various revenue sources. In this paper, we focus on the changes in the sharing schedules of enterprise tax in early 2000s. Although these changes apply to all provinces, the impact differs across the prefectures for two reasons. The first arises from the differing sharing schemes that each provincial government has with its own governing prefectures. Although the changes in the central-local sharing shame are uniform, the changes in the share retained by the prefectural government still vary by province. For example, after 2003 this share ranges from $16 \%$ in Yunnan to $40 \%$ in Guizhou. The shares assigned to the prefectural governments in different provinces for different time periods are presented in Figure 2. The second reason for regional variation originates from the fact that some prefectures depended on the enterprise tax more than did other prefectures. Where manufacturing formed the core of a prefecture's local economy, enterprise tax weighed more importantly, and vice versa. For these reasons, the change in the tax sharing schedule is thus expected to have different implications for local officials' behavior in different prefectures.

\section{Data and Summary Statistics}

In our analysis we focus on 1999 to 2005 - a period in which reliable prefecture-level data on land conveyance and transfer are available. We use prefecture as our unit of analysis for three reasons. Firstly, the prefecture is the lowest level for which data on land conveyance and transfer are available. Secondly, national policies have resulted in changing demarcation of county boundaries during the period under analysis, which presents problems for empirical estimation. The prefecture boundaries were rarely affected. Finally and most importantly, the prefectural government is most relevant for our analysis, to the extent that the re-assignment of enterprise tax has deprived it of an important source of revenue for fulfilling the public finance obligations and for other fiscal and career purposes, not to mention that, with the assigned authority to draw up the zoning plans and approve the conversion of agricultural land, it is a key player in the local land market.

urban migration (Fan, Li and Zhang, 2009). With that said, thanks to rising temporary migration China's urbanization rate has gone up drastically in recent years - from $30.68 \%$ in 1996 to $45.68 \%$ in 2009 (State Statistical Bureau, 2010). 
We obtain our data from three separate sources. First, the panel of land conveyance data for the period 1999-2005 is obtained from the Chinese Yearbook of Land Resource (Zhongguo Guotu Ziyuan Nianjian), published annually by the Ministry of Land and Resources (based on the annual records they maintain). These records contain information on the quantity and revenue of land conveyance in the primary land market as well as information of land transfers in the secondary market. Second, data on public finance, which includes various sources of government fiscal revenues for the same period, are obtained from the Fiscal Statistics for Prefectures, Municipalities and Counties (Quan Guo Di Shi Xian Caizheng Tongji Ziliao). Third, detailed prefecture-level economic and demographic information for the same period, 1999-2005 is obtained from the Statistical Yearbooks of China (Zhongguo Tongji Nianjian). This information includes GDP per capita, industrial output by ownership (domestic, foreign and Hong Kong, Taiwan \& Macau), population, and land area.

There are altogether 344 prefectures, but of these we are forced to drop 100. The 30 prefectures in Xinjiang and Tibet are dropped simply because of the lack of data, whereas another 70 have missing values in our key variables for at least two years prior to the change in the enterprise tax-sharing schedule in 2002. Among those 70 prefectures, 61 have missing values in domestic industrial output in 1999 and 2000 and the rest have missing values in land conveyance or fiscal revenue. Dropping those with missing values, we end up with 244 prefectures for which data are available for the period between 2000 and 2005. Note that of those 244 prefectures, only 212 have the needed data for the year 1999.

We present in Table 1 the summary statistics using the sample of 244 prefectures. ${ }^{10}$ All revenue terms have been adjusted to the 2000 Chinese yuan. ${ }^{11}$ We can see, for example, that average fiscal revenue increased from 1,548 million yuan in 1999 to 2,974 million yuan in 2005. Against this general trend of rising fiscal revenue is the declining share of enterprise tax. Accounting for $16 \%$ of the total fiscal revenue before year 2002, the pertinent share plummeted to $7.2 \%$ after the central government appropriated half of it from the local government in 2002, and to $5.4 \%$ in 2003 after the central government

\footnotetext{
${ }^{10}$ We also present in Table A.1 in the appendix the summary statistics for all prefectures by year excluding Xinjiang and Tibet. The statistics are strikingly similar to those given in table 1 .

${ }^{11} 8.5$ yuan $\approx 1$ U.S. dollar in 2000 .
} 
further increased its claim to $60 \%$. Conversely, land conveyance in the primary land market saw hefty increases in 2002 and 2003 in terms of both area and revenue. While land transfers in the secondary market exhibited a trend similar to that of the primary market, the primary market grew much faster - three times as much - in revenue terms during 1999-2004. The information on land transfers in the secondary land market is missing for year 2005. To demonstrate the public finance obligations of the prefectural governments, we also present the summary statistics of their fiscal expenditures in the Table A.2

As noted earlier, substantial variations exist in the mean values of the simulated changes in fiscal revenue, over time, across regions, and within region over time. Table 2 provides the pertinent information, on an annual basis, on the value of our simulated change in fiscal revenue as a share of overall fiscal revenue of the previous year using the subsample that contains information on all the variables and years. We present both the average value and standard deviation (in parentheses) for the different regions. By construction, the simulated changes in fiscal revenue are zero for the initial years of 20002001. In 2002, the simulated change accounts for an average of $4.0 \%$ reduction in fiscal revenue of the previous year. This ratio is distinctly higher in eastern China than in the less affluent central and western regions. In addition, there are also large variations within each region, which range from an insignificant $0.2 \%$ to a substantial $26.3 \%$. In temporal terms the simulated changes, at $1.4 \%$ on average, are more modest for year 2003. Nevertheless variations across regions remain substantial. And by 2004-2005 the simulated changes are back to zero again because by then the central-local tax sharing schedule had become stable.

\section{Empirical Strategy}

To explore the impact of changing fiscal incentives on local governments' policy choices, we borrow the simulated instrumental variable (SIV) approach developed by Dahl and Lochner (2012). The SIV approach exploits the discrete changes in the sharing schedule and filters out the endogenous response of prefectural governments by using the revenue in the previous period to simulate the changes in prefecture-retained fiscal revenue. It is thus well suited for our research purpose. We do not adopt the traditional instru- 
mental variable (IV) approach because it is difficult to find other exogenous variation to instrument changes in the prefecture-retained fiscal revenue, not to mention that the SIV framework allows us to relax the assumption of exclusion restrictions. We will first introduce our empirical model in Section 4.1, followed by describing the SIV approach in general and our particular way of addressing the potential problems that may arise when the underlying assumptions are relaxed in Section 4.2 .

\subsection{Empirical models of fiscal incentives}

We first specify how changes in prefecture fiscal revenue (through such policies as shared enterprise taxes with the central government) may affect the land conveyance behavior of prefecture governments in the following regression, assuming that the effects of prefecture fiscal revenue on land conveyance last for $L$ years:

$$
\ln y_{i t}=x_{i}^{\prime} \alpha_{t}+\omega_{i t}^{\prime} \beta+\delta_{0} \ln R_{i t}+\delta_{1} \ln R_{i, t-1}+\ldots+\delta_{L} \ln R_{i, t-L}+\mu_{i}+\epsilon_{i t}
$$

where $y_{i t}$ represents the area of land conveyance, $x_{i}$ represents a vector of observable permanent characteristics, $\omega_{i t}$ a vector of time-varying characteristics, and $R_{i t}$ the total prefecture-retained fiscal revenue for region $i$ at time $t$. For empirical purposes, we write the land conveyance equation in log-form.

The specification in equation (1) allows for different effects of the permanent characteristics at all times (i.e., $\alpha_{t}$ ). We allow the $x_{i}$ characteristics to affect both the level and growth of land conveyance. Taking the first-differences of equation (1) to eliminate the unobserved fixed effect $\mu_{i}$ yields:

$$
\Delta \ln y_{i t}=x_{i}^{\prime} \alpha+\Delta \omega_{i t}^{\prime} \beta+\Delta \ln R_{i t} \delta_{0}+\Delta \ln R_{i, t-1} \delta_{1}+\ldots+\Delta \ln R_{i, t-L} \delta_{L}+\Delta \epsilon_{i t}
$$

where $\alpha$ is the effect of $x_{i}$ on the growth of land conveyance.

We first use the "contemporaneous effects" model, which assumes $L=0$, as our baseline estimation model.

$$
\Delta l n y_{i t}=x_{i}^{\prime} \alpha+\Delta \omega_{i t}^{\prime} \beta+\Delta \ln R_{i t} \delta_{0}+\Delta \epsilon_{i t}
$$

We next consider the case where the revenue change has lasting effects on land conveyance. Due to data limitations, we are unable to estimate dynamic models that allow 
the effect to last for several years. Hence we include only the one-year lag of $\ln R$ in the specification, written as follows:

$$
\Delta \ln y_{i t}=x_{i}^{\prime} \alpha+\Delta \omega_{i t}^{\prime} \beta+\Delta \ln R_{i t} \delta_{0}+\Delta \ln R_{i, t-1} \delta_{1}+\Delta \epsilon_{i t}
$$

\subsection{Using changes in the tax-sharing schedule to estimate the effects of locally retained revenue on land conveyance}

The primary concern with the above estimations is that changes in the unobserved factors may affect land conveyance, i.e., $\Delta \epsilon_{i t}$ are correlated with changes in local fiscal revenue. More generally, $\Delta \epsilon_{i t}$ may be correlated with past levels of fiscal revenue. To address this problem, we employ the simulated instrumental variable (SIV) estimation strategy, which takes advantage of major changes in the tax sharing arrangement to estimate the effects of retained fiscal revenue on land conveyance. ${ }^{12}$ For simplicity, we focus on the 'contemporaneous effects' model of equation (3). A similar approach can be applied to estimate the more general models of equations (2) and (4).

For ease of exposition, we write the total fiscal revenue as follows:

$$
R_{i t}=I_{i t}+P_{i t}-\chi_{i t}\left(P_{i t}\right)
$$

where the part of the enterprise tax that goes to the upper-level government, ${ }^{13} \chi_{i t}\left(P_{i t}\right)$, is a function of the total enterprise tax $P_{i t}$; with $I_{i t}$ representing fiscal revenue from other sources.

This expression helps us understand the concerns regarding the estimation of equations (3) and (4). The first concern is the endogeneity problem. Note that both $I_{i t}$ and $P_{i t}$ may respond to the same changes in the tax sharing schedule. For example, the central government can increase the earmarked fiscal transfers to prefecture $i$, thereby raising $I_{i t}$, while simultaneously taking away a larger fraction of $P_{i t}$. Likewise, prefecture

\footnotetext{
${ }^{12}$ See Moffitt and Wilhelm (2000) for a general discussion of the SIV approach. Building on Feldstein (1995) and Currie and Gruber (1996), Gruber and Saez (2002) use this approach to estimate the elasticity of taxable income, whereas Dahl and Lochner (2012) analyze the impact of family income on child achievement by exploiting variation generated from the Earned Income Tax Credit.

${ }^{13}$ Because our unit of analysis is the prefecture, the upper-level government here refers to the central government and the provincial government.
} 
governments can respond by shifting their tax-collecting efforts among various types of taxes vis-a-vis cultivating new revenue sources. For instance, given that the bulk of business tax is obtained from the construction and real estate sectors, the decision to sell more land for real estate development would thus correspondingly result in an increase in business tax revenue, thereby raising $I_{i t}$. Another concern is that other policies implemented during the same period may also result in an appreciable increase in land sales. ${ }^{14}$

For our purpose, we are not concerned if the change in local revenue is a function of a prefecture's initial revenue and other fixed characteristics, because the fixed effects have already been eliminated by first-differencing. We would be worried, however, if the change in revenue is related to time-varying factors that affect future revenue streams and accordingly land conveyance behavior. To identify the causal impact of revenue change on land sales, we need only to find variations in the prefecture-retained fiscal revenue that is plausibly orthogonal to the time-varying determinants of land conveyance. Therefore we turn to the SIV strategy to address these concerns.

To construct the SIV for $\Delta \ln R_{i t}$, we exploit changes in the tax sharing schedule independent of local characteristics. We define the simulated instrument in such a way that it does not reflect the potentially endogenous revenue change:

$$
\Delta \ln \chi_{t}^{S I V}=\ln \left(I_{i, t-1}+P_{i, t-1}-\chi_{t}\left(P_{i, t-1}\right)\right)-\ln \left(I_{i, t-1}+P_{i, t-1}-\chi_{t-1}\left(P_{i, t-1}\right)\right) .
$$

By filtering the lagged pre-sharing enterprise tax through both the current and lagged sharing schedules, our instrument allows us to calculate the predicted change in a prefecture government's fiscal revenue. In other words, it reflects the change in fiscal revenue from period $t-1$ to $t$ that prefecture government $i$ would receive had their tax or revenue base remained the same as in period $t-1$. Thus it reflects only changes in the sharing schedule but not other changes in fiscal revenue, the latter of which may be correlated with $\Delta \epsilon_{i t}$.

As discussed in Section 3, two major changes occurred to the central-local revenuesharing formula: $\chi$ increased from 0 to $50 \%$ in 2002 and further increased to $60 \%$

\footnotetext{
${ }^{14}$ For example, while the magnitudes of agricultural taxes and fees are small in comparison with the magnitude of enterprise tax (Kung et al., 2010), one may still argue that the introduction of "tax-for-fee" reform in 2000 had resulted in local governments selling more land, insofar as the elimination of fees and levies on farm households by the village and township governments led to fiscal deficits.
} 
from 2003 onwards. The province-prefecture sharing schedules changed correspondingly. Moreover, to the extent that the importance of enterprise tax may likely vary significantly across prefectures, the aforementioned changes create substantial cross-sectional variations for estimating the elasticity of land conveyance with respect to the change in local budgetary revenue.

Since the simulated changes in a prefectural government's fiscal revenue is a function of period $t-1$ pre-sharing revenue $\left(R_{i, t-1}\right)$, the instrument $\Delta \ln \chi_{t}^{S I V}$ still produces biased estimates for $\delta_{0}$ if $\Delta \epsilon$ depends on $R_{i, t-1}$. This could possibly be due to a variety of reasons ranging from measurement error, regression to the mean, to serial correlations in revenue shocks. Therefore, following Gruber and Saez (2002), we further augment the outcome equation with a flexible function of $R_{i, t-1}$ and include the control of a linear time trend. Let $\Phi\left(\ln R_{i, t-1}\right)$ represent a flexible polynomial of lagged pre-sharing enterprise tax. We estimate

$$
\Delta l n y_{i t}=x_{i}^{\prime} \alpha+\Delta \omega_{i t}^{\prime} \beta+\Delta \ln R_{i t} \delta_{0}+\Phi\left(\ln R_{i, t-1}\right)+\mu t+\eta_{i t}
$$

using $\Delta \ln \chi_{t}^{S I V}$ as the instrument for $\Delta \ln R_{i t}$. One can think of the polynomial $\Phi\left(\ln R_{i, t-1}\right)$ as a control function, which implicitly equals $E\left[\Delta \epsilon_{i, t-1} \mid R_{i, t-1}, x_{i}, \Delta w_{i t}\right] .{ }^{15}$ In our estimation, we employ a 5 -piece spline in lagged fiscal revenue, in logarithm. Our results are not sensitive to even richer splines in the log of lagged fiscal revenue.

We rely on two fundamental assumptions in this framework: (i) the control function $\Phi(\cdot)$ must be flexible enough to capture the true expected relationship between shocks in the growth of land conveyance and lagged fiscal revenue (in log), and (ii) this relationship must be stable over time. In other words, we allow the relationship between $\Delta \epsilon$ and $\Delta l n R_{i, t-1}$ to be nonlinear, but assume that it is constant over time. If the revenue process is highly non-stationary (especially the joint density of $R_{i t}$ and $R_{i, t-1}$ changes over time), the second assumption is unlikely to hold. In this case, our SIV estimate would be biased, i.e., the effect of the fiscal revenue previously retained by the prefecture would not have been fully captured by the control function. While assumption (ii) is likely to be innocuous, we weaken this assumption modestly by allowing for a linear time trend in the splines of lagged fiscal revenue (in $\log$ ) and evaluate the sensitivity of our results accordingly.

\footnotetext{
${ }^{15}$ See Heckman and Robb (1985) for a general treatment of control functions.
} 
Since estimating the more general first-differencing models with the lagged changes in $\ln R$ such as equation (4) requires additional instruments for each new revenue term, we construct the instrument analogous to that described above for $\Delta \ln R_{i, t-1}$ in estimating equation (4):

$$
\Delta \ln \chi_{t-1}^{S I V}=\ln \left(I_{i, t-2}+P_{i, t-2}-\chi_{t-1}\left(P_{i, t-2}\right)\right)-\ln \left(I_{i, t-2}+P_{i, t-2}-\chi_{t-2}\left(P_{i, t-2}\right)\right)
$$

Note that this simulated IV uses the two-period lags of logged fiscal revenue, and thus requires the inclusion of a two-period lagged fiscal revenue (in log) in the control function. Therefore, we also include the splines of both the one-year and two-year lags of logged fiscal revenue as controls in estimating equation (4).

\section{Empirical Results}

\subsection{The Impact on Land Markets}

In this section we discuss the estimated impact of fiscal revenue retained by prefecture governments on the land markets. To establish the robustness of our findings, we examine a number of different specifications.

We begin with the area of land conveyed by prefecture governments in the primary market. Table 3 shows the OLS and SIV results obtained from our baseline estimations of the "contemporaneous effects" model. In these specifications, we control for the size of total population, non-agricultural population, land area at the prefecture level (all in logarithm) as well as the share of enterprise tax in fiscal revenue in 2001. To allow the time trend to differ by the importance of enterprise tax and by period, we also include the interaction between the linear time trend and the share of enterprise tax in fiscal revenue in 2001 and the interaction between the time trend and an indicator for post2002 period. As noted earlier, in the SIV model we use a 5-piece spline in the one-year lag of log fiscal revenue as our baseline "control function". For comparability, we use identical specifications for both OLS and SIV estimations.

We first estimate the specification that includes the splines in lagged fiscal revenue, a linear time trend, as well as all the controls mentioned above. The OLS and SIV estimates 
are reported in columns (1) and (4), respectively. Since both the outcome variable (land conveyance areas) and the variable of interest (prefecture-retained fiscal revenue) assume the form of changes in log, the estimated coefficient on the variable of interest can be interpreted as the elasticity of land conveyance areas with respect to prefecture-retained fiscal revenue. The OLS estimate (column (1) in table 3) of this elasticity is statistically significant at the $10 \%$ level and has a positive sign. However, once SIV is used to address the endogeneity issue, the results change drastically. The SIV estimate for this elasticity is significant at the $1 \%$ level, and the sign now turns negative. The estimated elasticity is around -6.47 (column (3) in table 3 ), which means that a $1 \%$ decrease in local fiscal revenue tends to raise the area of land conveyed by $6.47 \%$. The SIV estimate reveals that land conveyance systematically increased more in those regions where fiscal revenue was more adversely affected by changes in the tax-sharing schedule.

We further assess the sensitivity of our results to an alternative specification that modestly weakens the identifying assumption of a stable relationship between the one-year lagged fiscal revenue and changes in land conveyance behavior over time. This alternative specification allows for a linear time trend in the splines in fiscal revenue that form our central control function. The SIV estimates for this specification are presented in column (5) of table 3. The inclusion of interactions between a linear time trend and splines in fiscal revenue reduces the estimated elasticity to -6.36 - a magnitude remarkably similar to that in column (4). Hence, while we cannot completely rule out year-specific changes in the relationship between lagged fiscal revenue and land conveyance, the robustness of our results does suggest that they are unlikely driven by these changes.

To eliminate the potential time-invariant omitted variable bias, we further include the prefecture fixed effects. The OLS and SIV results are reported in columns (3) and (6) of Table 3 respectively. Upon including the prefecture fixed effects the OLS estimate becomes statistically insignificant and close to 0 in terms of magnitude, which suggests that at least some of the positive bias exists due to the fact that local governments in more developed regions are likely to engage more actively in land conveyance activities and to enjoy a wider tax base. In contrast, controlling for prefecture fixed effects in the SIV model yields a larger estimate - the estimated elasticity of land conveyance area with respect to fiscal revenue is -11.0 .

The discrepancy between our OLS and SIV estimates is striking when put in the 
context of local fiscal incentives. Although the media often attributes the sale of land use rights by local governments to the latter's loss of a substantial share of the enterprise tax (the so-called tudi caizheng or land-oriented fiscal budget, implying that local fiscal budgets are highly dependent on revenues from land sales.), ${ }^{16}$ the OLS result actually finds no strong correlation between these two quantities. ${ }^{17}$ But after eliminating the other confounding effects using the SIV approach, the alleged pattern reveals itself. There are several explanations for this discrepancy. First, the errors in the measurement of fiscal revenue tend to bias the OLS differenced estimators towards zero. Yet it is unlikely that this attenuation bias will change the sign of the coefficient of interest. A second and more important explanation is the time-variant omitted variable bias. To the extent that local governments obtain their revenues from a variety of sources, it is likely that they respond to changes in the tax-sharing schedules by investing effort in other tax-collecting activities besides selling more land. In particular, given that firms in urban areas or county seats pay a higher rate of city maintenance tax than those in suburban or rural areas, prefectures that convert more rural land to urban usages are thus more likely to collect more city maintenance tax. The revenue-hungry prefecture governments may also be less likely to grant tax breaks to local firms. These forces tend to bias the OLS estimators in an upward direction. In other words, local governments' effort in making up for the loss resulting from the reassignment of enterprise tax will increase both land sales and fiscal revenue.

To investigate the source of the endogeneity, we explore the response of land conveyance areas to the percentage change in the prefecture sharing rate of enterprise tax using the following alternative specification:

$$
\Delta l n y_{i t}=x_{i}^{\prime} \beta_{1}+\Delta \omega_{i t}^{\prime} \beta_{2}+\frac{\Delta S_{i t}}{S_{i, t-1}} \gamma_{0}+\Phi\left(\ln R_{i, t-1}\right)+\mu t+\eta_{i t}
$$

where $S_{i t}$ is the share of enterprise tax retained by prefecture $i$ in year $t$. By focusing on the percentage changes in the sharing rate, this specification thus avoids the endogenous changes in fiscal revenue. To make the results comparable to the OLS and SIV results, we use the same controls as in the OLS and SIV models. We also include the

\footnotetext{
${ }^{16}$ The journalistic reports on land-oriented fiscal budget are abundant; see, e.g., the People's Daily 2010/03/18, 2010/4/19, 2010/08/23.

${ }^{17}$ A previous study by Lichtenberg and Ding (2009) even finds a significant and positive relationship between local governments' revenue and the changing percentage share in the urban land area.
} 
interaction between the percentage change in the prefecture sharing rate and the share of enterprise tax in fiscal revenue in 2001 to examine whether the effect differs by the level of importance of enterprise tax in the local coffers.

Table 4 reports the estimated impacts of the prefecture-retained share of enterprise tax on the primary land market. Columns (1) and (2) present the estimates without and with prefecture fixed effects, respectively, for land conveyance areas. Similar to the SIV results, a decrease in the prefecture sharing rate resulted in an increase in the land conveyance area; moreover, the increase is greater in prefectures where enterprise tax previously accounted for a greater share of fiscal revenue.

We also explore the response of other tax revenues to the changes in the prefecture sharing rate of enterprise tax. The results are presented in Table 5. Columns (1) and (2) show the estimates for city maintenance tax without and with prefecture fixed effects respectively, while columns (3) and (4) show the estimates for value-added tax. All the estimates suggest that both sources of tax revenues increased in response to the reduced prefecture sharing rate of enterprise tax, which supports our conjecture of the omitted variable bias in the OLS models.

The findings from the alternative specification (9) illustrate that the SIV approach, which shuts down the channels for endogenous changes in fiscal revenue, yields more convincing estimates than the OLS models.

We now turn to examine the dependent variable measured in terms of land conveyance revenue. Table 6 reports the results of the contemporaneous effects model, which are similar to those measured in terms of the area of land conveyance. Without controlling for prefecture fixed effects, the OLS estimates (columns (1)-(2)) of the elasticity of land conveyance revenue with respect to prefecture-retained fiscal revenue are positive and statistically insignificant. Upon including prefecture fixed effects the OLS-estimated elasticity becomes negative albeit remaining statistically insignificant. In contrast, the SIV estimate (columns (4) and (5) in table 6) shows that a $1 \%$ decrease in prefectureretained fiscal revenue raises land conveyance revenue by approximately $10 \%$, which increases to $16 \%$ if controlling for prefecture fixed effects (column (6)).

Albeit larger in magnitude, the SIV estimates are in fact within a reasonable range. As shown in the summary statistics (table 1), the amount of land conveyance revenue is 
about the same as the amount of enterprise tax before 2002, i.e., approximately $10-15 \%$ of prefecture fiscal revenue. Other things being equal, reducing the enterprise tax by half reduces prefecture fiscal revenue by approximately $6 \%$. To compensate for this loss, it is reasonable to expect prefecture governments to seek additional revenues from other sources. Suppose that land conveyance revenue presents the only alternative revenue source, it would have to be increased by at least $60 \%$ to make up for the loss in budgetary revenue. In this case the elasticity of land conveyance revenue with respect to prefectureretained fiscal revenue is -10 , similar to the estimated elasticity.

If we take the estimated result (of -10) concerning the elasticity of land conveyance revenue with respect to locally retained fiscal revenue as the basis of calculation, a $5 \%$ decrease in prefecture-retained fiscal revenue will likely lead to an increase in land conveyance revenue by approximately $50 \%(10 \times 5 \%=50 \%)$. In light of the summary statistics in Table 1, which shows that land conveyance revenue increased by $96 \%$ from year 2001 to 2002, our result indicates that more than one half of this increase $(50 \%$ out of $96 \%$ ) can be explained by the observed $5 \%$ decline in prefecture-retained fiscal revenue that resulted in turn from the loss of the enterprise tax. These results suggest that the effect of fiscal centralization on local governments' policy choices in general, and land conveyance behavior in particular, is large.

It deserves mentioning that the magnitude of the elasticity measured in area terms is smaller than that measured in revenue terms. This suggests that, in response to changes in prefecture fiscal revenue, prefectural governments not only convey more land, but, where possible, also convey the more expensive land. A possible explanation is that prefectural governments have stronger preferences to convert land for residential or commercial use over industrial use. ${ }^{18}$ While the difference in prices between the two alternative usages in question is conceivably stemmed from the difference in location, the expectation that local governments should help foster local industrial growth by providing cheaper land figured importantly in the observed price differentials between industrial and commercial-cum-residential usages. ${ }^{19}$ If local governments indeed convert

\footnotetext{
${ }^{18}$ Our finding is similar to the results of Burnes, Neumark and White (2011) on the "fiscal zoning" of local government officials in the United States. They find that local officials in jurisdictions with higher sales tax rates tend to invest more effort in attracting large stores and shopping centers.

${ }^{19}$ Local governments often assigned land use rights to industrial users through either allocation (huabo) or negotiation (xieyi) (Ho and Lin, 2003) - mechanisms that have been banned since 2006 presumably
} 
more land for residential or commercial uses than they do for industrial use, it may well have increased the cost for the industrial firms. Unfortunately, we are unable to directly test this hypothesis due to the lack of detailed information on the exact usage of the converted land. Instead we adopt the changes in government spending on infrastructure as a proxy for the government's effort in urbanization. We apply the SIV approach to the infrastructure spending. The results are presented in Table 7. The OLS results in columns (1) - (3) show either an insignificant or marginally significant and positive relationship between changes in infrastructure spending and prefecture-retained fiscal revenue. However, after addressing the endogeneity problem using SIV, the significant causal relationship reemerges. The SIV results in columns (4) through (6) indicate that, a $1 \%$ reduction in prefecture-retained fiscal revenue leads to a $4.2-6.9 \%$ increase in government spending on infrastructure. This result supports our hypothesis that prefectural governments has invested more in urbanization.

As noted earlier, the key assumption underlying our empirical strategy is that the relationship between land conveyance and lagged fiscal revenue must remain stable over time. A challenge to this assumption is that the housing market experienced a sharp increase in demand at the same time as the tax-sharing schedule underwent changes, to the extent that local governments may have responded by "selling" more land to meet the sudden rise in demand in the housing market. Had our SIV also captured the surge in housing demand, the SIV estimates would have mistakenly attributed the increase in land conveyance to the decrease in fiscal revenue.

To address this concern, we conduct a placebo test by examining the changes in land transfers (tudi zhuanrang) in the secondary market. The underlying logic is this: if the SIV captures the surge in the land demand, land transfers in the secondary market should also exhibit patterns similar to those of land conveyance in the primary market. In particular, the surge in demand in the housing market should have resulted in price increases in the secondary market beyond increases in the area transferred.

We thus apply the same empirical strategy as we did in the previous subsection to analyze both trading volume and revenue of land transfers, and report the pertinent results in table 8. Columns (1)-(3) and (4)-(5) of Panel A, which present the OLS and SIV because such processes lacked transparency and were thus prone to corruption (State Council 2006 No. $31)$. 
estimates for the elasticity of land transfer area with respect to prefecture-retained revenue, show that the estimates are statistically insignificant. The OLS estimates (columns (1)-(3) of Panel B) for land transfer revenue suggest negative correlation between land transfer revenue and prefecture-retained fiscal revenue. However, the SIV estimates are statistically insignificant. Moreover, the pertinent magnitudes are much smaller compared to the elasticity estimates of the conveyance area and revenue. These results thus rule out the concern that the estimated impact of reduced fiscal revenue on land conveyance is driven by the accelerating demand for land instead of the changing fiscal needs of prefectural governments.

We further drop the assumption of "contemporaneous effects" and turn to explore the dynamic models that allow for the likelihood that reductions in prefecture-retained fiscal revenue have a lagged effect on the land market. Estimates of equation (4) are reported in table 9. Our key findings, in this context, are two-fold. First, virtually all the estimates suggest that the long-run effects of revenue change on land conveyance behavior are negligible. Second, the contemporaneous effects of prefecture-retained fiscal revenue on land conveyance in the primary market in terms of both area and revenue remain sizable. The estimated elasticities for both the area and revenue of land conveyed are, respectively, -3.15 and -4.98 (columns (1) and (2) in table 9), magnitudes that are smaller than the estimates in the contemporaneous effects models (tables 3 and $6)$. Again, the insignificant effects of changing revenue-sharing on land transfers in the secondary market (columns (3) and (4) in table 9) lend further support to the findings of the contemporaneous effects models (table 8).

\subsection{The Impact on Industrial Growth}

Our SIV results show that the loss of prefecture-retained fiscal revenue has a highly significant effect on prefectural governments' land conveyance behavior and infrastructure spending. An immediate question arising from this robust finding is whether fiscal recentralization may affect industrial growth in a negative way. The shift in development focus from industrialization to urbanization does not necessarily retard industrial growth 
if urbanization and industrialization are complementary. ${ }^{20}$ Because of the extraordinarily active role that they play in the economic development process, local governments' involvement in both industrialization and urbanization are substantial. Which of the two they choose to put greater emphasis, therefore, depends on the expected relative returns.

Prior to fiscal recentralization and the allocation of property rights to local governments as residual claimants of land revenues, rural industrialization had been an engine of growth for many prosperous regions. But the quest for industrialization was weakened by both a smaller share of the original tax revenues (and also the heightened competition among regions), on the one hand, and land conveyance fees on the other. In addition, the incentive for industrialization has likely become further weakened by the higher returns of real estate development. Indeed, evidence clearly suggests that, in regions that relied primarily on industrial growth for land revenues, competition for manufacturing investments among localities were so keen that the price of industrial land were often driven down substantially (Lin and Ho, 2005; Zhou, 2007; Ming Pao 2007, May 8 and 11, A29). Small wonder, therefore, that local governments that are able to attract commercial and real estate developments have increasingly turned to auctioning land usufruct rights to real estate development. In these regions, commercial and real estate developments will most likely "crowd out" manufacturing endeavors. We now turn to examine this topic empirically.

In doing so it is important that we draw a distinction between foreign and domestic firms, primarily because a dent in the incentives to drive industrial growth is likely to have very different impacts on these two types of firms. The reason is, because of the favorable tax policies and holidays that foreign and Hong Kong, Taiwan and Macau (HTM) firms enjoyed, ${ }^{21}$ domestic firms have contributed disproportionately more to the local coffers. ${ }^{22}$ Hence, any weakening of the incentives on the part of local governments

\footnotetext{
${ }^{20}$ Using data from the late 1980s to 2000, Deng et al. (2008) find that economic growth was the main driver of urbanization, whereas industrialization had only a small, albeit also positive effect.

${ }^{21}$ For instance, the enterprise tax rate prior to 2008 was $33 \%$ for domestic enterprises but only $15 \%$ for foreign firms. Additionally, many local governments used tax rebates and other exemptions to attract foreign firms.

${ }^{22}$ The industrial output of firms with foreign, Hong Kong, Macau or Taiwan ownership is approximately $1 / 3$ of that of domestic firms. Taking into account the favorable tax policies enjoyed by these non-
} 
to continue with the quest for industrialization will have predictably stronger effects on domestic firms than on foreign firms.

Table 10 presents the results on the elasticity of domestic industrial output with respect to changes in fiscal revenue-sharing. Columns (1) and (4) report the OLS and SIV estimates for the specification that includes the splines in lagged fiscal revenue and a linear time trend, columns (2) and (5) report results based on the specification that also includes the interaction between splines and the time trend, whereas columns (3) and (6) report results after controlling for prefecture fixed effects. Both the OLS and SIV estimates show that increases in prefecture-retained fiscal revenue have a positive and statistically significant effect on the growth of domestic industrial output. However, the SIV estimates are larger. The OLS estimates show that domestic industrial output would decline by $0.09 \%-0.21 \%$ if the central government redistributes $1 \%$ of the local fiscal revenue to itself while SIV estimates show that domestic industrial output would decline by $0.69 \%-0.90 \%$.

The discrepancy between the OLS and SIV estimates reported in Table 10 is also sizable. The OLS estimates tend to be biased downward if shifting development focus toward urbanization simultaneously increases other tax revenue (and hence increases the prefecture retained fiscal revenue) while stunting industrial growth, i.e., the sign of this omitted variable bias is negative. The discrepancy is relatively small compared to that between the OLS and SIV estimates for land conveyance. A likely reason is that the shift in effort made by local governments affects industrial growth only indirectly. The magnitude of this confounding effect thus tends to be small.

The impacts of changing fiscal revenue-sharing and accordingly incentives on the industrial output of foreign and HTM firms are different, however (Table 11). Neither the OLS estimates with prefecture fixed effects (columns (3)) nor the SIV estimates (columns (4)-(5)) suggest the existence of a strong relationship between prefecture-retained fiscal revenue and foreign industrial output - a result consistent with our conjecture that changes in fiscal incentives are more likely to hurt domestic firms than foreign firms. This result also suggests that changes in domestic industrial growth are unlikely caused by business cycles or other shocks that would affect the whole economy.

domestic firms, their contribution to local fiscal revenue is no more than $1 / 6$ of that of domestic firms. 
As a robustness check, we also apply the alternative specification (9) to the domestic and non-domestic industrial output. Reported in Table 12, the results are consistent with the SIV estimates.

We examine the dynamic models that allow for the effects of fiscal revenue on industrial output to lag. The SIV estimates of equation (4) are presented in table 13, which shows that the estimated contemporaneous effect for domestic industrial output is positive but statistically insignificant. A possible reason for the loss of statistical significance is that we have had to drop more observations when we included the lagged change in fiscal revenue. As far as the industrial output of foreign firms is concerned, both contemporaneous and long-run effects of the changes in prefecture retained revenue are negligible - a finding that is also consistent with the estimates of the contemporaneous models.

There are multiple channels through which a reduction in prefecture-retained revenue can negatively impact the industrial growth. Given that local governments own the land under their administrative jurisdictions, revenue-hungry local governments are more predisposed to sell land use rights to real estate developers who typically pay much higher conveyance fees than the industrialists, subject only to the quota constraint on land conversion, ${ }^{23}$ which tends to increase the cost of requisitioning land for industrial usage. Our finding in Section 6.1 that prefectural governments tend to sell more expensive land is consistent with this story. Another possible channel is through local governments' changing tax effort. The reassignment of enterprise tax may render prefectural governments less willing to grant firms tax exemptions or breaks and, conversely, more eager to crack down on tax evasion. Our evidence on city maintenance tax and value-added tax is consistent with this story. Zheng (2014) also provides evidence that the effective tax burden has increased to a greater extent for manufacturing firms in prefectures more adversely affected by the enterprise tax reassignment, and, consistent with that reasoning, that the number of new firms has decreased to a greater extent in these prefectures. Together, they suggest that tax effort is a likely channel through which local governments' fiscal incentives affect industrial growth. Other channels possibly coexist with these two direct channels and merit further study.

\footnotetext{
${ }^{23}$ The state has officially set quotas on land conversion. Although local governments have strong incentives to circumvent the law, the risks of disciplinary sanctions add additional costs to unauthorized land conveyance (Kung, Xu and Zhou, 2013).
} 


\section{Conclusion}

In theory, fiscal incentives can affect "a surprisingly wide variety of policy choices" (Weingast, 2009). However, few studies have systematically tested this hypothesis. Fortunately, the exogenous policy changes in the intergovernmental fiscal revenue sharing scheme in China allow us to conduct this empirical test. By drawing on a data set uniquely constructed from several pertinent sources, we test the fiscal incentive thesis at a level (prefecture) where the alleged incentives are clearly stronger than those at the provincial level. And by using the simulated instrumental variable (SIV) strategy, we are able to satisfactorily deal with a number of endogeneity issues arising from unobserved local conditions that go beyond our list of control variables - a prominent example being local governments' possibly adjusting their marginal tax efforts in response to changes in fiscal revenue-sharing arrangements.

In summary, we find that, in response to the changing fiscal revenue-sharing rules which reduce local governments' allocation of enterprise tax revenue, local governments have increasingly shifted their focus to cultivating new revenue bases by exploiting their assigned monopoly rights in land. In particular, they allocate more effort to converting arable land for urban, commercial usages or to what may be considered an "inorganic" urbanization process at the expense of industrial growth - particularly the growth of domestically-owned firms. Previous works that compare the development paths of China

and other developing countries such as India and Russia have noted the importance of local governments in fueling economic growth. Our findings demonstrate that fiscal arrangements, with the high-powered incentives they provide for officials to achieve growth and other goals pertaining to public finance and their own political careers, importantly shape local governments' behavior. 


\section{References}

[1] Akai, Nobuo and Masayo Sakata. 2002. "Fiscal decentralization contributes to eco-

nomic growth: evidence from state-level cross-section data for the United States." Journal of Urban Economics, 52(1), July 2002, pages 93 -108.

[2] Bardhan, Pranab, and Dilip Mookherjee. 2006. "The Rise of Local Governments: An Overview." in Decentralization and Local Governance in Developing Countries: A Comparative Perspective, ed. by Pranab Bardhan and Dilip Mookherjee, Cambridge: MIT press.

[3] Baretti, Huber and Lichtblau. 2002. "A Tax on Tax Revenue: The Incentive Effects of Equalizing Transfers: Evidence from Germany." International Tax and Public Finance, 9(6), p. 631-649.

[4] Blanchard, Oliver and Andrew Shleifer. 2001. "Federalism with and without Political Centralization: China versus Russia. in Transitional Economics: How Much Progress?" IMF Staff Papers.

[5] Büttner, Thiess. 2006. "The Incentive Effect of Fiscal Equalization Transfers on Tax Policy." Journal of Public Economics, 90(3), p. 477-497.

[6] Burnes, Daria, David Neumark and Michelle White. 2011. "Fiscal Zoning and Sales Taxes: Do Higher Sales Taxes Lead to More Retailing and Less Manufacturing?" NBER Working paper 16932.

[7] Cai, Hongbin and Daniel Treisman. "Did Government Decentralization Cause China's Economic Miracle?" World Politics, 58(04), p. 505-535.

[8] Careaga, Maite, and Barry R. Weingast. 2003. "Fiscal federalism, good governance, and economic growth in Mexico." in Dani Rodrik (Ed.), Search of Prosperity: Analytic Narratives on Economic Growth, Princeton University Press, Princeton.

[9] Chang, Chun and Yuiang Wang. 1994. "The Nature of the Town-Village Enterprise." Journal of Comparative Economics, 19, p. 434-452. 
[10] Currie, Janet and Jonathan Gruber. 1996. "Saving Babies: The Efficacy and Cost of Recent Changes in the Medicaid Eligibility of Pregnant Women." Journal of Political Economy, 106(6): 1263 - 1296.

[11] Dahlby, Bev. 2002. "The incentive effects of fiscal equalization." in: Boothe, P. (ed.): Equalization: Welfare Trap or Helping Hand?, Halifax.

[12] Dahl, Gordon and Lance Lochner. 2012. "The Impact of Family Income on Child Achievement: Evidence from the Earned Income Tax Credit." American Economic Review, 102(5), p. 1927-1956.

[13] Deng, Xiangzheng, Jikun Huang, Scott Rozelle, Emi Uchida. 2008. "Growth, population and industrialization, and urban land expansion of China." Journal of Urban Economics, 63(1), p. 96-115.

[14] Enikolopova, Ruben and Ekaterina Zhuravskayab. 2007. "Decentralization and political institutions." Journal of Public Economics, 91(11-12), p. 2261-2290.

[15] Fan, Shenggen, Li Lixing and Zhang Xiaobo. 2009. "Rethinking China's Underurbanization: An Evaluation of Its County-to-City Upgrading Policy." IFPRI Discussion Paper 00875 .

[16] Feldstein, Martin. 1995. "Behavioral Responses to Tax Rates: Evidence from the Tax Reform Act of 1986." American Economic Review, 85(2), p. 170 - 74.

[17] Gordon, Roger, and Wei Li. 2011. "Provincial and Local Governments in China: Fiscal Institutions and Government Behavior." NBER working paper 16694.

[18] Gruber, Jon and Emmanuel Saez. 2002. "The elasticity of taxable income: evidence and implications." Journal of Public Economics, 84(1), p. 1-32.

[19] Heckman, James J. and Robb, Richard Jr., 1985. "Alternative methods for evaluating the impact of interventions : An overview." Journal of Econometrics, 30(1-2), p. 239-267.

[20] Ho, Samuel P.S. and George C.S. Lin. 2003. "Emerging Land Markets in Rural and Urban China: Policies and Practices." The China Quarterly, 175, p. 681-707.

[21] Iimi, Atsushi. 2005. "Decentralization and Economic Growth Revisited: an Empirical Note." Journal of Urban Economics, 57(3), May 2005, p. 449-461. 
[22] Jin, Hehui, and Yingyi Qian. 1998. "Public Versus Private Ownership of Firms: Evidence from Rural China." Quarterly Journal of Economics, 113(3), p. 773-808.

[23] Jin, Hehui, Yingyi Qian and Barry R. Weingast. 2005. "Regional decentralization and fiscal incentives: Federalism, Chinese style." Journal of Public Economics, 89(910), p. $1719-1742$.

[24] Kung, James, and Yimin Lin. 2007. "The decline of township-and-village enterprises in China's economic transition." World Development, 35(4), p. 569-584.

[25] Kung, James, Chenggang Xu and Feizhou Zhou. 2013. "From industrialization to urbanization: the social consequences of changing fiscal incentives on local governments' behavior." Forthcoming in Joseph E. Stiglitz (ed.), Institutional Design for Chinas Evolving Market Economy. New York: Oxford University Press.

[26] Kung, James, Yongshun Cai, Ying Bai, Yang Zhao and Feizhou Zhou. 2010. "Why did China abolish its agricultural tax? Clues from the limitations of the tax-for-free reform." mimeo.

[27] Li, Hongbin and Li-an Zhou. 2005. "Political Turnover and Economic Performance: The Incentive Role of Personnel Control in China." Journal of Public Economics, 89 (9-10): 1743-1762.

[28] Li, Hongbin, and Scott Rozelle. 2003. "Privatizing rural China: insider privatization, innovative contracts, and the performance of township enterprises." China Quarterly, 176(December), 981-1105.

[29] Li, Hongbin, and Scott Rozelle. 2004. "Insider privatization with a tail: the buyout price and performance of privatized firms in China." Journal of Development Economics, 75(1), 1-26.

[30] Lichtenberg, Erik and Chengri Ding. 2009. "Local officials as land developers: Urban spatial expansion in China." Journal of Urban Economics, 66(1), p. 57-64.

[31] Lin, George C.S. and Samuel P. S. Ho. 2005. "The State, Land System, and Land Development Processes in Contemporary China." Annals of the Association of American Geographers, 95(2), p. 411-436. 
[32] Martinez-Vazquez, Jorge, and Robert M. McNab. 2003. "Fiscal Decentralization and Economic Growth." World Development, Vol. 31, No. 9, p. 1597-1616.

[33] Maskin, Eric, Yingyi Qian, and Chenggang Xu. 2000. "Incentives, Information, and Organizational Form." Review of Economic Studies, 67 (2): 359-378.

[34] McKinnon, Ronald. 1997. "Market-preserving Federalism in the American Monetary Union," in M. Blejer and T. Ter-Minassian (eds.), Macroeconomic Dimensions of Public Finance: Essays in Honour of Vito Tanzi. London: Routledge, 73-93.

[35] Moffitt, Robert A. and Mark Wilhelm. 2000. "Taxation and the Labor Supply Decisions of the Affluent." Economics Working Paper Archive 414, The Johns Hopkins University,Department of Economics.

[36] Montinola, Gabriella, Yingyi Qian and Barry R. Weingast. 1995. "Federalism, Chinese Style: The Political Basis for Economic Success in China." World Politics, 48(1), p. $50-81$.

[37] Oi, Jean C. 1992. "Fiscal Reform and the Economic Foundations of Local State Corporatism in China." World Politics, 45(1), p. 99-126.

[38] Oi, Jean C. 1999. Rural China Takes Off: Institutional Foundations of Economic Reform. Berkeley: University of California Press.

[39] Qian, Yingyi, and Chenggang Xu. 1993. "The M-form Hierarchy and China's Economic Reform." European Economic Review, 43, p. 541-548.

[40] Qian, Yingyi and Barry Weingast. 1997. "Federalism as a commitment to perserving market incentives." Journal of Economic Perspectives, 11(4), p. 83-92.

[41] Rao, M. Govinda and Nirvikar Singh. 2005. Political Economy of Federalism in India. Oxford University Press, New Delhi.

[42] Riker, William H. 1964. Federalism: origin, operation, significance. Boston: Little Brown.

[43] Rodden, Jonathan. 2003. "Reviving Leviathan: Fiscal Federalism and the Growth of Government." International Organization, 57: p. 695-729. 
[44] Singh, Nirvikar and Srinivasan, T.N., 2006. "Federalism and economic development in India: An assessment." MPRA Paper 12452, University Library of Munich, Germany.

[45] Smart, Michael. 1998. "Taxation and deadweight loss in a system of intergovernmental transfers." Canadian Journal of Economics, 31, 189-206.

[46] Thornton, John. 2007. "Fiscal decentralization and economic growth reconsidered." Journal of Urban Economics, 61(1), p. 64-70.

[47] Wang, Jin. 2010. "Fiscal Incentive and Effort Allocation by Governments: Evidence from China." mimeo.

[48] Wong, Christine. 2007. "Budget Reform in China." OECD Journal of Budgeting, $7(1)$, pages 33-56.

[49] Wong, Christine and Richard Bird. 2008. "Fiscal System in China: A Work in Progress." In China's Great Economic Transformation, Loren B., Thomas G.R. (e.d.). Cambridge University Press: Cambridge; p. 429-466.

[50] Weingast, Barry. 1995. "The Economic Role of Political Institutions: MarketPreserving Federalism and Economic Development." Journal of Law, Economics, and Organization, 11(1): p. 1-33.

[51] Weingast, Barry R.. 2009. "Second generation fiscal federalism: The implications of fiscal incentives." Journal of Urban Economics, 65(3), p. 279-293.

[52] Xu, Chenggang. 2011. "The Fundamental Institutions of Chinas Reforms and Development." Journal of Economic Literature, 49(4), p. 1076-1151.

[53] Zheng, Runze. 2014. "Fiscal incentives of local governments and enterprise tax burden: firm-level evidence from China." M.phil thesis, The Hong Kong University of Science and Technology.

[54] Zhou, Feizhou. 2007. "The Road to Riches: Governments and Peasants in Land Development [Shengcai youdao: tudi kaifa zhong de zhengfu he nongmin]", The Sociological Study [Shehuixue yanjiu], 1: 49-82.

[55] Zhuravskaya, Ekaterina V. 2000. "Incentives to Provide Local Public Goods: Fiscal Federalism, Russian Style." Journal of Public Economics, 76(3), p. 337-368. 
Figure 1: The Central-Local Tax Sharing Schedules $\%$ retained by province and below

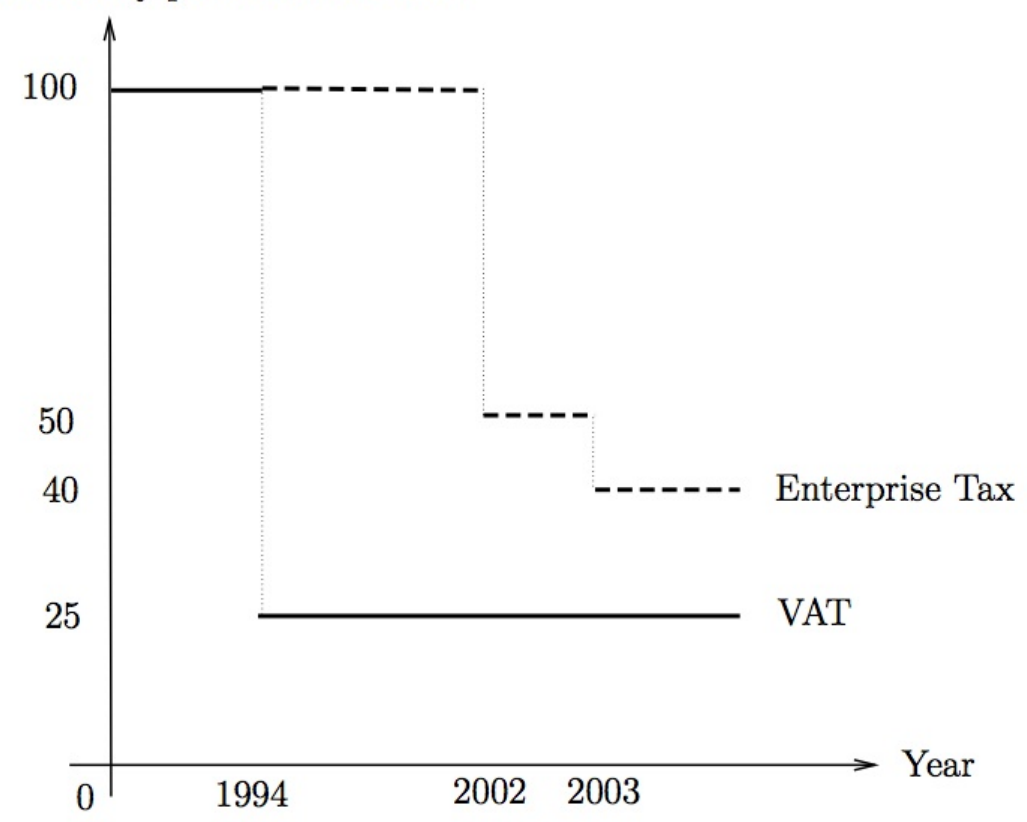


Figure 2: The Prefecture-retained Share of Enterprise Tax by Province and Year

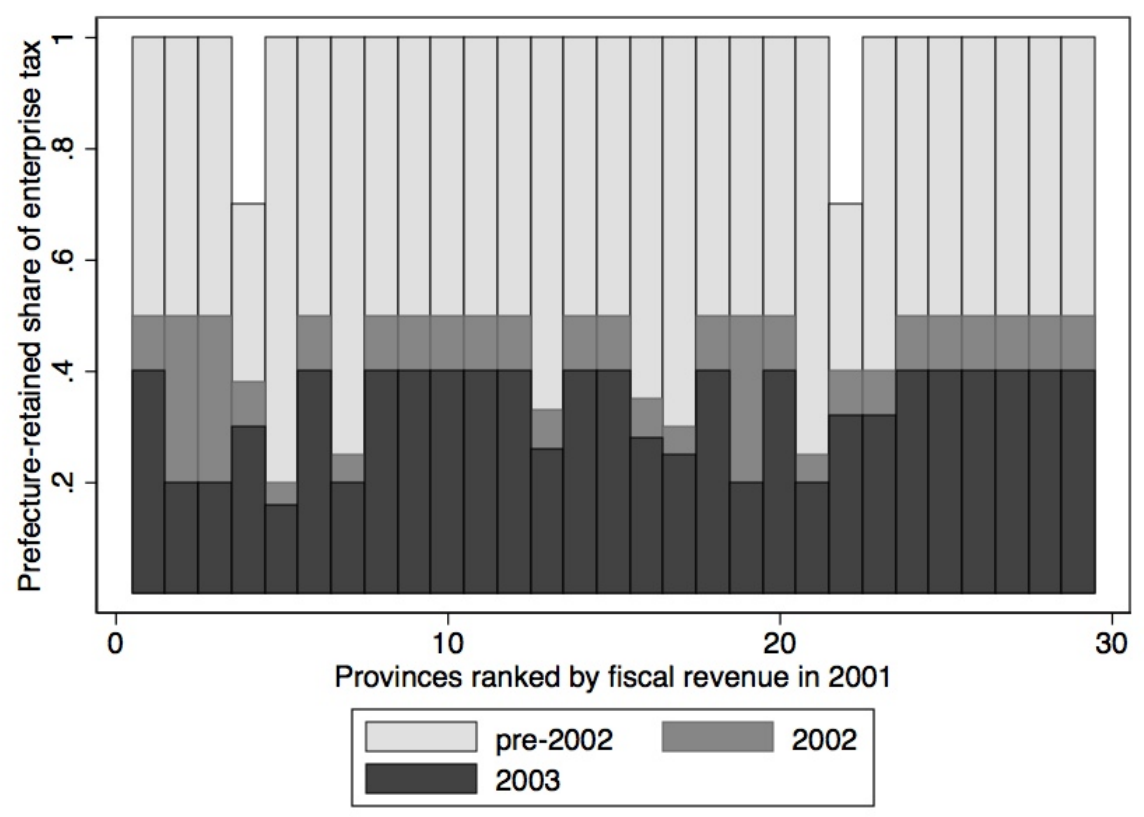




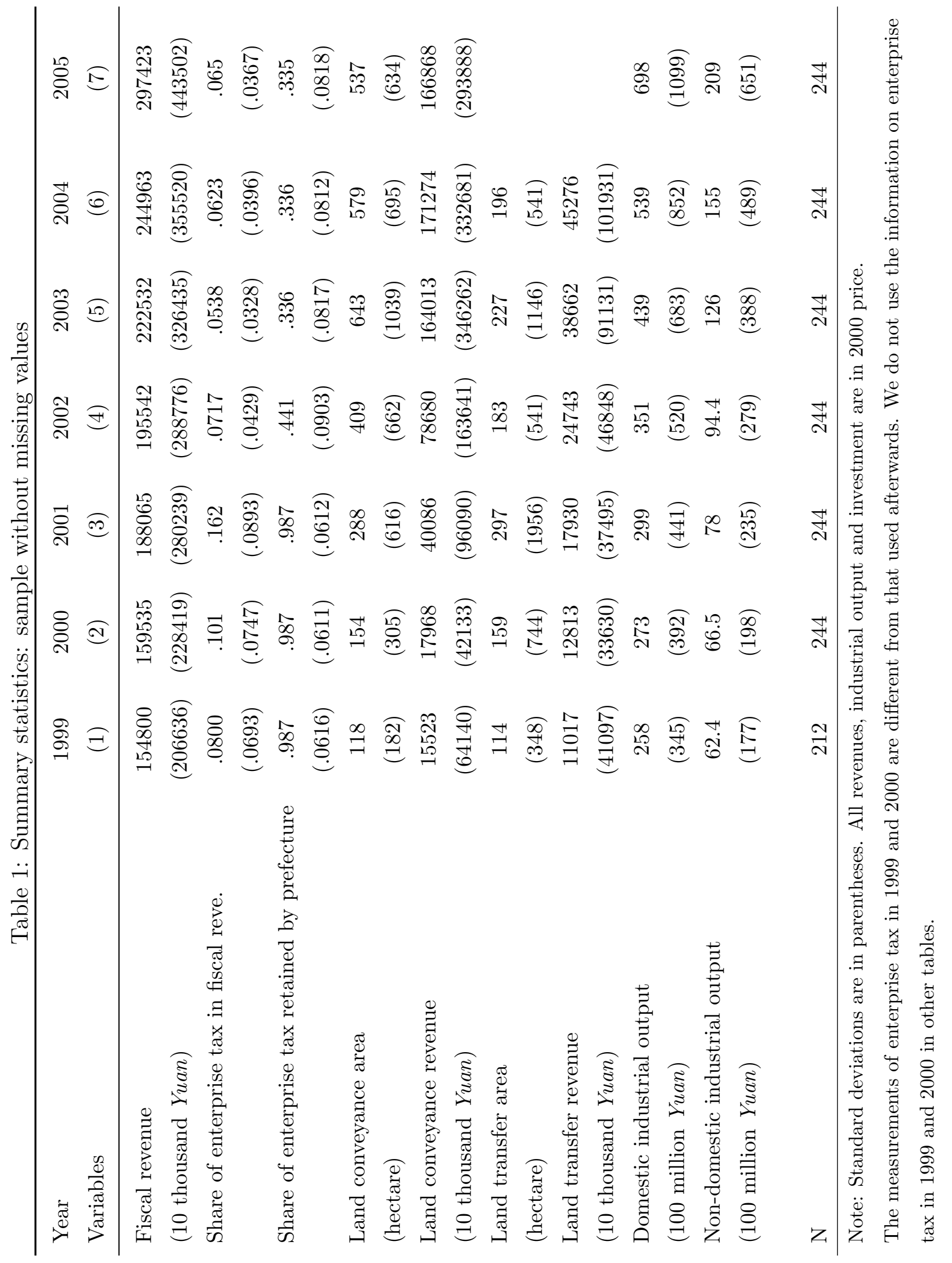


Table 2: Source of Variation:

changes in retained enterprise tax as share of fiscal revenue

\begin{tabular}{lcccc}
\hline & \multicolumn{4}{c}{$\left(\Delta\left(\chi_{i, t}\left(P_{i, t-1}\right)-\chi_{i, t-1}\left(P_{i, t-1}\right)\right) / R_{i, t-1}\right.$} \\
\cline { 2 - 5 } & \multicolumn{4}{c}{ Mean(s.d. $)$} \\
\cline { 2 - 5 } & National & East & Middle & West \\
\cline { 2 - 5 } $2000-2001$ & 0 & 0 & 0 & $(4)$ \\
& $(1)$ & $(0)$ & $(0)$ & 0 \\
2002 & -.0406 & -.0539 & -.0312 & -.0337 \\
& $(.0239)$ & $(.0245)$ & $(.0174)$ & $(.0224)$ \\
2003 & -.014 & -.0192 & -.00976 & -.0122 \\
& $(.00952)$ & $(.00993)$ & $(.00604)$ & $(.00967)$ \\
$2004-2005$ & 0 & 0 & 0 & 0 \\
& $(0)$ & $(0)$ & $(0)$ & $(0)$ \\
$\mathrm{N}$ & 244 & 96 & 98 & 50 \\
\hline
\end{tabular}


Table 3: The Impact on Land Conveyance Area

\begin{tabular}{|c|c|c|c|c|c|c|}
\hline & \multicolumn{6}{|c|}{ Dept. var.: $\Delta \log ($ land conveyance area $)$} \\
\hline & \multirow[b]{2}{*}{$(1)$} & OLS & \multirow[b]{2}{*}{$(3)$} & \multirow[b]{2}{*}{$(4)$} & SIV & \multirow[b]{2}{*}{$(6)$} \\
\hline & & $(2)$ & & & $(5)$ & \\
\hline \multicolumn{7}{|l|}{ 1st stage coefficient } \\
\hline \multirow[t]{2}{*}{ SIV } & & & & $0.576^{* * *}$ & $0.579 * * *$ & $0.393^{* * *}$ \\
\hline & & & & $(0.0916)$ & $(0.0918)$ & $(0.0794)$ \\
\hline \multirow[t]{2}{*}{$\Delta \log (\operatorname{tax}$ reve $)$} & $0.429^{*}$ & $0.422^{*}$ & 0.005 & $-6.472^{* * *}$ & $-6.356^{* * *}$ & $-11.010^{* * *}$ \\
\hline & $(0.239)$ & $(0.239)$ & $(0.333)$ & $(1.753)$ & $(1.736)$ & $(3.128)$ \\
\hline \multirow[t]{2}{*}{ Log(population) } & 0.034 & 0.034 & -0.206 & $-0.223^{* *}$ & $-0.224^{* *}$ & 0.321 \\
\hline & $(0.038)$ & $(0.037)$ & $(0.294)$ & $(0.110)$ & $(0.110)$ & $(0.974)$ \\
\hline \multirow[t]{2}{*}{ Log(nonagri. population) } & 0.032 & 0.030 & 0.175 & 0.166 & 0.163 & 0.307 \\
\hline & $(0.043)$ & $(0.043)$ & $(0.211)$ & $(0.111)$ & $(0.110)$ & $(0.449)$ \\
\hline \multirow[t]{2}{*}{ Log(land area) } & -0.016 & -0.016 & $0.317^{* *}$ & -0.078 & -0.075 & 0.412 \\
\hline & $(0.023)$ & $(0.023)$ & $(0.107)$ & $(0.053)$ & $(0.053)$ & $(0.377)$ \\
\hline \multirow[t]{2}{*}{$\mathrm{t}$} & -0.078 & 1.208 & 2.179 & $0.470^{* *}$ & 2.274 & 2.332 \\
\hline & $(0.080)$ & $(2.003)$ & $(2.343)$ & $(0.159)$ & $(2.598)$ & $(3.470)$ \\
\hline \multirow[t]{2}{*}{ Share of Firm tax in 2001} & 0.325 & 0.046 & . & $4.213^{* *}$ & $3.995^{* *}$ & . \\
\hline & $(0.542)$ & $(0.546)$ & . & $(1.448)$ & $(1.505)$ & . \\
\hline \multirow[t]{2}{*}{ post $\times \mathrm{t}$} & 0.004 & 0.002 & -0.011 & $-0.238^{* *}$ & $-0.235^{* *}$ & $-0.357^{* *}$ \\
\hline & $(0.046)$ & $(0.046)$ & $(0.047)$ & $(0.075)$ & $(0.074)$ & $(0.111)$ \\
\hline \multirow[t]{2}{*}{$\mathrm{t} \times$ Share of firm tax } & -0.121 & -0.055 & 0.053 & $-0.617^{* *}$ & $-0.570^{* *}$ & 0.344 \\
\hline & $(0.099)$ & $(0.100)$ & $(0.109)$ & $(0.252)$ & $(0.267)$ & $(0.303)$ \\
\hline Splines of lagged $\log$ (fiscal reve.) & yes & yes & yes & yes & yes & yes \\
\hline $\mathrm{t} \times$ Splines of lagged $\log ($ fiscal reve $)$ & no & yes & yes & no & yes & yes \\
\hline Prefecture fixed effects & no & no & yes & no & no & yes \\
\hline R-square & 0.0275 & 0.0292 & 0.034 & 0.0003 & 0.0002 & 0.0004 \\
\hline $\mathrm{N}$ & 1432 & 1432 & 1432 & 1432 & 1432 & 1432 \\
\hline
\end{tabular}

Note: Robust standard errors, clustered at the prefecture level, are reported in parentheses.

* Significant at the $10 \%$ level; ** $5 \%$; *** $1 \%$. 
Table 4: An Alternative Approach: Land Conveyance

\begin{tabular}{|c|c|c|c|c|}
\hline \multirow[t]{2}{*}{ Outcome var. } & \multicolumn{2}{|c|}{$\Delta \log ($ conveyance area $)$} & \multicolumn{2}{|c|}{$\Delta \log ($ conveyance revenue $)$} \\
\hline & $(1)$ & $(2)$ & $(3)$ & $(4)$ \\
\hline$\% \Delta$ prefecture share rate & $\begin{array}{c}-0.613^{* *} \\
(0.269)\end{array}$ & $\begin{array}{c}-0.632^{* *} \\
(0.273)\end{array}$ & $\begin{array}{c}-1.625^{* * *} \\
(0.392)\end{array}$ & $\begin{array}{c}-1.635^{* * *} \\
(0.394)\end{array}$ \\
\hline $\begin{array}{l}\% \Delta \text { prefecture share rate } \times \text { Share } \\
\text { of firm tax }\end{array}$ & $\begin{array}{l}-2.851^{* *} \\
(1.094)\end{array}$ & $\begin{array}{c}-3.289^{* *} \\
(1.111)\end{array}$ & $\begin{array}{l}-1.639 \\
(1.545)\end{array}$ & $\begin{array}{l}-2.090 \\
(1.517)\end{array}$ \\
\hline Share of Firm tax in 2001 & $\begin{array}{c}0.252 \\
(0.609)\end{array}$ & . & $\begin{array}{l}1.494^{*} \\
(0.867)\end{array}$ & . \\
\hline $\mathrm{t}$ & $\begin{array}{c}0.306^{* *} \\
(0.119)\end{array}$ & $\begin{array}{c}0.339^{* *} \\
(0.119)\end{array}$ & $\begin{array}{c}0.508^{* *} \\
(0.187)\end{array}$ & $\begin{array}{l}0.553^{* *} \\
(0.187)\end{array}$ \\
\hline Post $\times \mathrm{t}$ & $\begin{array}{c}-0.229^{* *} \\
(0.071)\end{array}$ & $\begin{array}{c}-0.248^{* * *} \\
(0.072)\end{array}$ & $\begin{array}{c}-0.356^{* *} \\
(0.113)\end{array}$ & $\begin{array}{c}-0.369^{* *} \\
(0.114)\end{array}$ \\
\hline $\mathrm{t} \times$ Share of Firm tax & $\begin{array}{l}-0.151 \\
(0.104)\end{array}$ & $\begin{array}{c}0.072 \\
(0.114)\end{array}$ & $\begin{array}{c}-0.351^{* *} \\
(0.155)\end{array}$ & $\begin{array}{l}-0.170 \\
(0.151)\end{array}$ \\
\hline Log(land area) & $\begin{array}{l}-0.024 \\
(0.024)\end{array}$ & $\begin{array}{c}0.362^{* * *} \\
(0.093)\end{array}$ & $\begin{array}{c}-0.086^{* *} \\
(0.034)\end{array}$ & $\begin{array}{c}0.027 \\
(0.217)\end{array}$ \\
\hline $\log ($ population $)$ & $\begin{array}{c}0.009 \\
(0.036)\end{array}$ & $\begin{array}{l}-0.180 \\
(0.309)\end{array}$ & $\begin{array}{c}0.077 \\
(0.057)\end{array}$ & $\begin{array}{c}0.383 \\
(0.696)\end{array}$ \\
\hline $\log ($ nonagri. population) & $\begin{array}{c}0.061 \\
(0.045)\end{array}$ & $\begin{array}{c}0.162 \\
(0.212)\end{array}$ & $\begin{array}{c}0.063 \\
(0.076)\end{array}$ & $\begin{array}{l}-0.034 \\
(0.363)\end{array}$ \\
\hline Splines of lagged $\log (\operatorname{tax}$ reve.) & yes & yes & yes & yes \\
\hline Prefecture fixed effects & no & yes & no & yes \\
\hline R-square & 0.052 & 0.064 & 0.067 & 0.075 \\
\hline $\mathrm{N}$ & 1432 & 1432 & 1432 & 1432 \\
\hline
\end{tabular}

Note: Robust standard errors, clustered at the prefecture level, are reported in parentheses.

* Significant at the $10 \%$ level; ** $5 \%$; *** $1 \%$. 
Table 5: An Alternative Approach: Other taxes

\begin{tabular}{|c|c|c|c|c|}
\hline \multirow[t]{2}{*}{ Outcome var. } & \multicolumn{2}{|c|}{$\Delta \log ($ city improvement tax $)$} & \multicolumn{2}{|c|}{$\Delta \log (V A T)$} \\
\hline & $(1)$ & $(2)$ & $(3)$ & $(4)$ \\
\hline$\% \Delta$ prefecture share rate & $\begin{array}{c}-0.209^{* * *} \\
(0.055)\end{array}$ & $\begin{array}{c}-0.197^{* * *} \\
(0.053)\end{array}$ & $\begin{array}{c}-0.145^{* *} \\
(0.063)\end{array}$ & $\begin{array}{l}-0.108^{*} \\
(0.059)\end{array}$ \\
\hline $\begin{array}{l}\% \Delta \text { prefecture share rate } \times \text { Share } \\
\text { of firm tax }\end{array}$ & $\begin{array}{c}0.068 \\
(0.348)\end{array}$ & $\begin{array}{l}-0.003 \\
(0.333)\end{array}$ & $\begin{array}{l}-0.165 \\
(0.220)\end{array}$ & $\begin{array}{c}-0.561^{* *} \\
(0.242)\end{array}$ \\
\hline Share of Firm tax in 2001 & $\begin{array}{c}0.339 * * \\
(0.166)\end{array}$ & . & $\begin{array}{c}0.237 \\
(0.169)\end{array}$ & . \\
\hline $\mathrm{t}$ & $\begin{array}{l}-0.009 \\
(0.013)\end{array}$ & $\begin{array}{l}-0.014 \\
(0.013)\end{array}$ & $\begin{array}{c}0.149 * * * \\
(0.018)\end{array}$ & $\begin{array}{c}0.160 * * * \\
(0.017)\end{array}$ \\
\hline Post $\times t$ & $\begin{array}{l}0.022^{* *} \\
(0.008)\end{array}$ & $\begin{array}{l}0.022^{* *} \\
(0.008)\end{array}$ & $\begin{array}{c}-0.070^{* * *} \\
(0.010)\end{array}$ & $\begin{array}{c}-0.072^{* * *} \\
(0.010)\end{array}$ \\
\hline $\mathrm{t} \times$ Share of Firm tax & $\begin{array}{l}-0.037 \\
(0.029)\end{array}$ & $\begin{array}{c}0.010 \\
(0.033)\end{array}$ & $\begin{array}{l}-0.040 \\
(0.032)\end{array}$ & $\begin{array}{l}0.130^{* *} \\
(0.044)\end{array}$ \\
\hline Log(land area) & $\begin{array}{l}-0.007 \\
(0.007)\end{array}$ & $\begin{array}{l}-0.017 \\
(0.044)\end{array}$ & $\begin{array}{c}0.003 \\
(0.008)\end{array}$ & $\begin{array}{c}0.081^{* * *} \\
(0.021)\end{array}$ \\
\hline $\log ($ population $)$ & $\begin{array}{l}-0.011 \\
(0.009)\end{array}$ & $\begin{array}{l}-0.094 \\
(0.087)\end{array}$ & $\begin{array}{c}-0.031^{* *} \\
(0.013)\end{array}$ & $\begin{array}{c}0.372^{* * *} \\
(0.103)\end{array}$ \\
\hline $\log ($ nonagri. population) & $\begin{array}{l}-0.013 \\
(0.014)\end{array}$ & $\begin{array}{c}0.033 \\
(0.041)\end{array}$ & $\begin{array}{c}0.008 \\
(0.016)\end{array}$ & $\begin{array}{l}-0.010 \\
(0.055)\end{array}$ \\
\hline Splines of lagged $\log ($ tax reve.) & yes & yes & yes & yes \\
\hline Prefecture fixed effects & no & yes & no & yes \\
\hline R-square & 0.1812 & 0.198 & 0.0697 & 0.131 \\
\hline $\mathrm{N}$ & 1432 & 1432 & 1432 & 1432 \\
\hline
\end{tabular}

Note: Robust standard errors, clustered at the prefecture level, are reported in parentheses.

* Significant at the $10 \%$ level; ** $5 \%$; *** $1 \%$. 
Table 6: The Impact on Revenue from land conveyance

\begin{tabular}{|c|c|c|c|c|c|c|}
\hline & \multicolumn{6}{|c|}{ Dept. var.: $\Delta \log ($ land conveyance revenue $)$} \\
\hline & \multirow[b]{2}{*}{$(1)$} & OLS & \multirow[b]{2}{*}{$(3)$} & \multirow[b]{2}{*}{$(4)$} & SIV & \multirow[b]{2}{*}{$(6)$} \\
\hline & & $(2)$ & & & $(5)$ & \\
\hline \multicolumn{7}{|l|}{ 1st stage coefficient } \\
\hline \multirow[t]{2}{*}{ SIV } & & & & $0.576^{* * *}$ & $0.579 * * *$ & $0.393^{* * *}$ \\
\hline & & & & $(0.0916)$ & $(0.0918)$ & $(0.0794)$ \\
\hline \multirow[t]{2}{*}{$\Delta \log ($ tax reve $)$} & 0.325 & 0.321 & -0.288 & $-10.056^{* * *}$ & $-9.997 * * *$ & $-16.314^{* * *}$ \\
\hline & $(0.293)$ & $(0.291)$ & $(0.352)$ & $(2.601)$ & $(2.580)$ & $(4.602)$ \\
\hline \multirow[t]{2}{*}{ Log(population) } & 0.088 & 0.088 & 0.393 & $-0.336^{* *}$ & $-0.338^{* *}$ & 1.301 \\
\hline & $(0.054)$ & $(0.055)$ & $(0.696)$ & $(0.166)$ & $(0.166)$ & $(1.385)$ \\
\hline \multirow[t]{2}{*}{ Log(nonagri. population) } & 0.027 & 0.014 & -0.077 & 0.242 & 0.228 & 0.022 \\
\hline & $(0.072)$ & $(0.074)$ & $(0.370)$ & $(0.162)$ & $(0.161)$ & $(0.640)$ \\
\hline \multirow[t]{2}{*}{ Log(land area) } & $-0.068^{* *}$ & $-0.070^{* *}$ & -0.044 & $-0.153^{* *}$ & $-0.152^{* *}$ & 0.066 \\
\hline & $(0.034)$ & $(0.034)$ & $(0.235)$ & $(0.076)$ & $(0.076)$ & $(0.531)$ \\
\hline \multirow[t]{2}{*}{$\mathrm{t}$} & -0.130 & $8.097 * * *$ & $10.045^{* *}$ & $0.700 * *$ & $8.784^{* *}$ & $9.835^{* *}$ \\
\hline & $(0.110)$ & $(2.442)$ & $(3.363)$ & $(0.236)$ & $(3.740)$ & $(4.995)$ \\
\hline \multirow[t]{2}{*}{ Share of Firm tax in 2001} & $1.522^{*}$ & 1.144 & . & $7.178^{* * *}$ & $6.868^{* *}$ & . \\
\hline & $(0.815)$ & $(0.850)$ & . & $(2.091)$ & $(2.166)$ & . \\
\hline \multirow[t]{2}{*}{ post $\times \mathrm{t}$} & 0.039 & 0.036 & 0.021 & $-0.328^{* *}$ & $-0.329^{* *}$ & $-0.489 * *$ \\
\hline & $(0.064)$ & $(0.065)$ & $(0.065)$ & $(0.110)$ & $(0.110)$ & $(0.163)$ \\
\hline \multirow[t]{2}{*}{$\mathrm{t} \times$ Share of Firm tax } & $-0.341^{* *}$ & -0.257 & -0.157 & $-1.057^{* *}$ & $-0.989^{* *}$ & 0.335 \\
\hline & $(0.151)$ & $(0.158)$ & $(0.156)$ & $(0.363)$ & $(0.384)$ & $(0.439)$ \\
\hline Splines of lagged $\log$ (fiscal reve.) & yes & yes & yes & yes & yes & yes \\
\hline $\mathrm{t} \times$ Splines of lagged $\log ($ fiscal reve $)$ & no & yes & yes & no & yes & yes \\
\hline Prefecture fixed effects & no & no & yes & no & no & yes \\
\hline R-squared & 0.0286 & 0.0353 & 0.029 & 0.000 & 0.0002 & 0.0004 \\
\hline $\mathrm{N}$ & 1432 & 1432 & 1432 & 1432 & 1432 & 1432 \\
\hline
\end{tabular}

Note: Robust standard errors, clustered at the prefecture level, are reported in parentheses.

* Significant at the $10 \%$ level; ** 5\%; *** $1 \%$. 
Table 7: The Impact on Infrastructure Spending

\begin{tabular}{|c|c|c|c|c|c|c|}
\hline & \multicolumn{6}{|c|}{ Dept. var.: $\Delta \log ($ infrastructure spending $)$} \\
\hline & \multirow[b]{2}{*}{$(1)$} & \multirow{2}{*}{$\frac{\mathrm{OLS}}{(2)}$} & \multirow[b]{2}{*}{$(3)$} & \multirow[b]{2}{*}{$(4)$} & SIV & \multirow[b]{2}{*}{ (6) } \\
\hline & & & & & $(5)$ & \\
\hline \multicolumn{7}{|l|}{ 1st stage coefficient } \\
\hline \multirow[t]{2}{*}{ SIV } & & & & $0.576^{* * *}$ & $0.579^{* * *}$ & $0.393^{* * *}$ \\
\hline & & & & $(0.0916)$ & $(0.0918)$ & $(0.0794)$ \\
\hline \multirow[t]{2}{*}{$\Delta \log ($ tax reve $)$} & 0.333 & 0.324 & $0.531^{*}$ & $-4.173^{* *}$ & $-4.387 * *$ & $-6.896^{* *}$ \\
\hline & $(0.210)$ & $(0.211)$ & $(0.281)$ & $(1.902)$ & $(1.863)$ & $(3.364)$ \\
\hline \multirow[t]{2}{*}{ Log(population) } & 0.019 & 0.007 & 0.315 & -0.152 & -0.142 & 0.846 \\
\hline & $(0.057)$ & $(0.058)$ & $(0.292)$ & $(0.108)$ & $(0.158)$ & $(0.760)$ \\
\hline \multirow[t]{2}{*}{ Log(nonagri. population) } & -0.025 & -0.020 & -0.101 & 0.091 & 0.280 & -0.159 \\
\hline & $(0.080)$ & $(0.079)$ & $(0.237)$ & $(0.108)$ & $(0.203)$ & $(0.349)$ \\
\hline \multirow[t]{2}{*}{ Log(land area) } & 0.056 & 0.061 & -0.168 & 0.012 & -0.044 & -0.111 \\
\hline & $(0.038)$ & $(0.038)$ & $(0.104)$ & $(0.050)$ & $(0.094)$ & $(0.280)$ \\
\hline \multirow[t]{2}{*}{$\mathrm{t}$} & 0.027 & -1.042 & 2.521 & $0.370^{* *}$ & 0.593 & 1.083 \\
\hline & $(0.056)$ & $(2.615)$ & $(3.347)$ & $(0.159)$ & $(2.993)$ & $(4.279)$ \\
\hline \multirow[t]{2}{*}{ Share of Firm tax in 2001} & 0.474 & $1.043^{*}$ & . & $2.903^{* *}$ & $4.241^{* *}$ & . \\
\hline & $(0.633)$ & $(0.623)$ & . & $(1.378)$ & $(1.556)$ & . \\
\hline \multirow[t]{2}{*}{ Post $\times t$} & -0.035 & -0.032 & -0.026 & $-0.186^{* *}$ & $-0.189^{* *}$ & $-0.234^{* *}$ \\
\hline & $(0.032)$ & $(0.032)$ & $(0.034)$ & $(0.073)$ & $(0.071)$ & $(0.103)$ \\
\hline \multirow[t]{2}{*}{$\mathrm{t} \times$ Share of Firm tax } & -0.011 & -0.135 & $-0.275^{* *}$ & -0.300 & $-0.420^{* *}$ & 0.088 \\
\hline & $(0.140)$ & $(0.138)$ & $(0.137)$ & $(0.219)$ & $(0.204)$ & $(0.290)$ \\
\hline Splines of lagged $\log$ (fiscal reve.) & yes & yes & yes & yes & yes & yes \\
\hline $\mathrm{t} \times$ Splines of lagged $\log ($ fiscal reve $)$ & no & yes & yes & no & yes & yes \\
\hline Prefecture fixed effects & no & no & yes & no & no & yes \\
\hline R-square & 0.0137 & 0.0187 & 0.013 & 0.0005 & 0.0000 & 0.0011 \\
\hline $\mathrm{N}$ & 1264 & 1264 & 1264 & 1264 & 1264 & 1264 \\
\hline
\end{tabular}

Note: Robust standard errors, clustered at the prefecture level, are reported in parentheses.

* Significant at the $10 \%$ level; ** $5 \%$; *** $1 \%$. 
Table 8: Placebo Test: Impact on Land Transfer in the Secondary Market

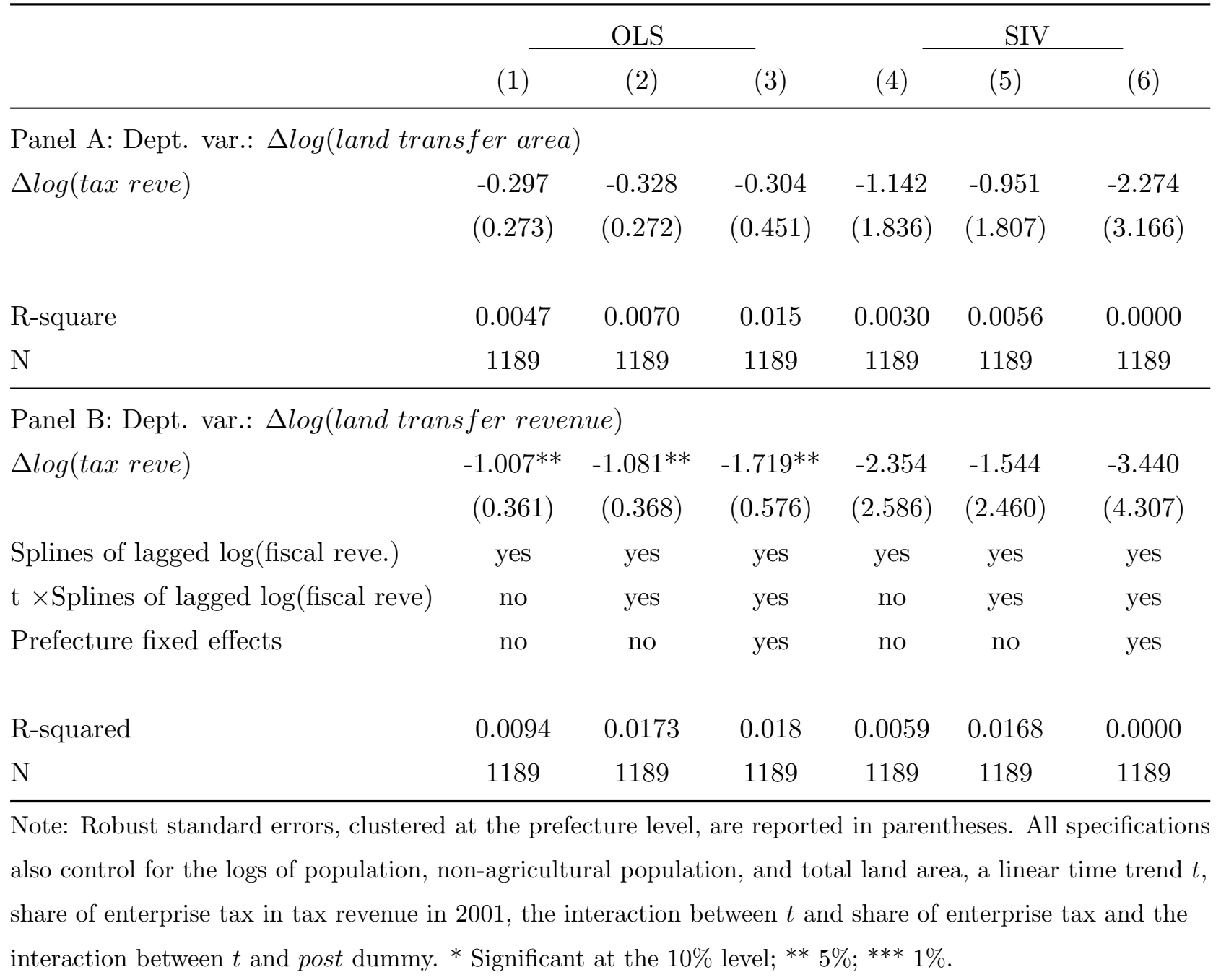


Table 9: Estimates of Long-run effects on Land Market

\begin{tabular}{lcccc}
\hline & \multicolumn{2}{c}{ Land conveyance } & \multicolumn{2}{c}{ Land transfer } \\
\cline { 2 - 4 } & Area & Revenue & Area & Revenue \\
\cline { 2 - 4 } & $(1)$ & $(2)$ & $(3)$ & $(4)$ \\
\hline$\Delta \log ($ taxreve $)$ & $-3.154^{*}$ & $-4.975^{* *}$ & -1.159 & -1.577 \\
$\Delta \log _{-1}($ tax reve $)$ & -0.094 & 0.258 & 0.941 & 1.371 \\
& $(1.790)$ & $(2.381)$ & $(2.152)$ & $(2.407)$ \\
R-squared & 0.0124 & $(1.875)$ & $(1.621)$ & $(3.377)$ \\
$\mathrm{N}$ & 1215 & 1215 & 972 & \\
\hline
\end{tabular}

Note: Robust standard errors, clustered at the prefecture level, are reported

in parentheses. All specifications also control for the logs of population, nonagricultural population, total land area, the 5-piece splines of lagged tax revenue, a linear time trend $t$, post $\times \mathrm{t}$, the interaction between $t$ and share of enterprise tax in 2001 and prefecture fixed effects.

* Significant at the $10 \%$ level; ** $5 \%$; *** $1 \%$. 
Table 10: The Impact on Domestic Industrial Output

\begin{tabular}{|c|c|c|c|c|c|c|}
\hline & \multicolumn{6}{|c|}{ Dept. var.: $\Delta \log ($ domestic indu. output $)$} \\
\hline & \multirow[b]{2}{*}{ (1) } & OLS & \multirow[b]{2}{*}{$(3)$} & \multirow[b]{2}{*}{$(4)$} & SIV & \multirow[b]{2}{*}{$(6)$} \\
\hline & & $(2)$ & & & $(5)$ & \\
\hline \multicolumn{7}{|l|}{ 1st stage coefficient } \\
\hline \multirow[t]{2}{*}{ SIV } & & & & $0.516^{* * *}$ & $0.496^{* * *}$ & $0.376^{* * *}$ \\
\hline & & & & $(0.0785)$ & $(0.0763)$ & $(0.0783)$ \\
\hline \multirow[t]{2}{*}{$\Delta \log ($ taxreve $)$} & $0.214^{* * *}$ & $0.213^{* * *}$ & $0.091^{* *}$ & $0.691^{* *}$ & $0.714^{* *}$ & $0.896^{* *}$ \\
\hline & $(0.040)$ & $(0.040)$ & $(0.034)$ & $(0.234)$ & $(0.244)$ & $(0.366)$ \\
\hline \multirow[t]{2}{*}{ Log(population) } & $0.026^{* *}$ & $0.026^{* *}$ & $0.198^{* *}$ & 0.020 & -0.002 & 0.152 \\
\hline & $(0.010)$ & $(0.010)$ & $(0.096)$ & $(0.027)$ & $(0.039)$ & $(0.110)$ \\
\hline \multirow[t]{2}{*}{ Log(nonagri. population) } & $-0.040^{* *}$ & $-0.041^{* *}$ & $0.106^{*}$ & -0.022 & 0.007 & $0.102^{* *}$ \\
\hline & $(0.015)$ & $(0.015)$ & $(0.058)$ & $(0.033)$ & $(0.042)$ & $(0.051)$ \\
\hline \multirow[t]{2}{*}{ Log(land area) } & $-0.014^{*}$ & $-0.014^{* *}$ & -0.055 & -0.007 & -0.006 & -0.061 \\
\hline & $(0.007)$ & $(0.007)$ & $(0.064)$ & $(0.016)$ & $(0.023)$ & $(0.042)$ \\
\hline \multirow[t]{2}{*}{$\mathrm{t}$} & -0.008 & 0.271 & 0.172 & $-0.048^{* *}$ & 0.199 & 0.183 \\
\hline & $(0.011)$ & $(0.195)$ & $(0.155)$ & $(0.021)$ & $(0.344)$ & $(0.395)$ \\
\hline \multirow[t]{2}{*}{ Share of Firm tax in 2001} & $0.222^{* *}$ & $0.205^{* *}$ & . & -0.106 & -0.202 & . \\
\hline & $(0.081)$ & $(0.087)$ & . & $(0.236)$ & $(0.305)$ & . \\
\hline \multirow[t]{2}{*}{ Post $\times \mathrm{t}$} & $0.028^{* * *}$ & $0.028^{* * *}$ & $0.024^{* * *}$ & $0.045^{* * *}$ & $0.045^{* * *}$ & $0.049^{* * *}$ \\
\hline & $(0.007)$ & $(0.007)$ & $(0.007)$ & $(0.010)$ & $(0.010)$ & $(0.013)$ \\
\hline \multirow[t]{2}{*}{$\mathrm{t} \times$ Share of Firm tax } & -0.025 & -0.021 & -0.002 & 0.007 & 0.002 & -0.027 \\
\hline & $(0.019)$ & $(0.020)$ & $(0.021)$ & $(0.029)$ & $(0.029)$ & $(0.035)$ \\
\hline Splines of lagged $\log$ (tax reve.) & yes & yes & yes & yes & yes & yes \\
\hline $\mathrm{t} \times$ Splines of lagged $\log ($ tax reve $)$ & no & yes & yes & no & yes & yes \\
\hline Prefecture fixed effects & no & no & yes & no & no & yes \\
\hline R-squared & 0.179 & 0.183 & 0.185 & 0.1244 & 0.0996 & 0.0139 \\
\hline $\mathrm{N}$ & 1432 & 1432 & 1432 & 1432 & 1432 & 1432 \\
\hline
\end{tabular}

Note: Robust standard errors, clustered at the prefecture level, are reported in parentheses.

* Significant at the $10 \%$ level; ** $5 \%$; *** $1 \%$. 
Table 11: The Impact on Industrial Output of Non-domestic Firms

\begin{tabular}{|c|c|c|c|c|c|c|}
\hline & \multicolumn{6}{|c|}{ Dept. var.: $\Delta \log ($ non - domestic indu. output $)$} \\
\hline & \multirow[b]{2}{*}{ (1) } & OLS & \multirow[b]{2}{*}{ (3) } & \multirow[b]{2}{*}{ (4) } & SIV & \multirow[b]{2}{*}{ (6) } \\
\hline & & (2) & & & (5) & \\
\hline \multicolumn{7}{|l|}{ 1st stage coefficient } \\
\hline \multirow[t]{2}{*}{ SIV } & & & & $0.516^{* * *}$ & $0.496^{* * *}$ & $0.376^{* * *}$ \\
\hline & & & & $(0.0785)$ & $(0.0763)$ & $(0.0783)$ \\
\hline \multirow[t]{2}{*}{$\Delta \log ($ tax reve $)$} & $0.236^{*}$ & $0.237^{*}$ & 0.158 & 0.362 & 0.376 & 0.452 \\
\hline & $(0.129)$ & $(0.128)$ & $(0.181)$ & $(0.645)$ & $(0.640)$ & $(1.038)$ \\
\hline \multirow[t]{2}{*}{$\log ($ population) } & -0.021 & -0.018 & -0.405 & -0.015 & -0.018 & -0.422 \\
\hline & $(0.022)$ & $(0.022)$ & $(0.290)$ & $(0.041)$ & $(0.050)$ & $(0.311)$ \\
\hline \multirow[t]{2}{*}{ Log(nonagri. population) } & 0.014 & 0.015 & 0.313 & 0.010 & 0.029 & $0.311^{* *}$ \\
\hline & $(0.028)$ & $(0.028)$ & $(0.206)$ & $(0.040)$ & $(0.054)$ & $(0.144)$ \\
\hline \multirow[t]{2}{*}{ Log(land area) } & 0.010 & 0.009 & 0.057 & 0.011 & 0.010 & 0.055 \\
\hline & $(0.013)$ & $(0.013)$ & $(0.068)$ & $(0.019)$ & $(0.025)$ & $(0.119)$ \\
\hline \multirow[t]{2}{*}{$\mathrm{t}$} & 0.021 & $-1.171^{* *}$ & -0.835 & 0.011 & -1.197 & -0.831 \\
\hline & $(0.023)$ & $(0.593)$ & $(0.734)$ & $(0.058)$ & $(0.946)$ & $(1.120)$ \\
\hline \multirow[t]{2}{*}{ Share of Firm tax in 2001} & 0.136 & 0.174 & . & 0.060 & 0.119 & . \\
\hline & $(0.215)$ & $(0.246)$ & . & $(0.515)$ & $(0.544)$ & \\
\hline \multirow[t]{2}{*}{ Post $\times \mathrm{t}$} & 0.003 & 0.003 & -0.004 & 0.007 & 0.008 & 0.006 \\
\hline & $(0.011)$ & $(0.011)$ & $(0.012)$ & $(0.027)$ & $(0.027)$ & $(0.037)$ \\
\hline \multirow[t]{2}{*}{$\mathrm{t} \times$ Share of Firm tax } & 0.023 & 0.014 & 0.000 & 0.032 & 0.024 & -0.009 \\
\hline & $(0.047)$ & $(0.055)$ & $(0.059)$ & $(0.089)$ & $(0.091)$ & $(0.099)$ \\
\hline Splines of lagged $\log$ (tax reve.) & yes & yes & yes & yes & yes & yes \\
\hline $\mathrm{t} \times$ Splines of lagged $\log (\operatorname{tax}$ reve $)$ & no & yes & yes & no & yes & yes \\
\hline Prefecture fixed effects & no & no & yes & no & no & yes \\
\hline R-squared & 0.0281 & 0.0304 & 0.029 & 0.0274 & 0.0293 & 0.0028 \\
\hline $\mathrm{N}$ & 1432 & 1432 & 1432 & 1432 & 1432 & 1432 \\
\hline
\end{tabular}

Note: Robust standard errors, clustered at the prefecture level, are reported in parentheses.

* Significant at the $10 \%$ level; ** $5 \%$; *** $1 \%$. 
Table 12: An Alternative Approach: Impact on the Industrial Output

\begin{tabular}{|c|c|c|c|c|}
\hline \multirow[t]{3}{*}{ Outcome var } & \multicolumn{4}{|c|}{$\Delta \log ($ Industrial Output $)$} \\
\hline & \multicolumn{2}{|c|}{ Domestic firms } & \multicolumn{2}{|c|}{ Non-domestic firms } \\
\hline & (1) & $(2)$ & $(3)$ & $(4)$ \\
\hline \multirow[t]{2}{*}{$\% \Delta$ Prefecture share rate } & $0.104^{* * *}$ & $0.115^{* * *}$ & -0.051 & -0.040 \\
\hline & $(0.030)$ & $(0.032)$ & $(0.077)$ & $(0.078)$ \\
\hline \multirow[t]{2}{*}{$\% \Delta$ Prefecture share rate $\times$ Share of firm tax } & -0.003 & -0.050 & 0.352 & 0.284 \\
\hline & $(0.150)$ & $(0.173)$ & $(0.279)$ & $(0.292)$ \\
\hline \multirow[t]{2}{*}{ Share of Firm tax in 2001} & $0.332^{* * *}$ & . & 0.326 & . \\
\hline & $(0.097)$ & . & $(0.218)$ & . \\
\hline \multirow[t]{2}{*}{$\mathrm{t}$} & $-0.025^{*}$ & $-0.034^{* *}$ & 0.039 & 0.044 \\
\hline & $(0.013)$ & $(0.013)$ & $(0.036)$ & $(0.036)$ \\
\hline \multirow[t]{2}{*}{ Post $\times t$} & $0.042^{* * *}$ & $0.042^{* * *}$ & -0.004 & -0.006 \\
\hline & $(0.008)$ & $(0.008)$ & $(0.020)$ & $(0.022)$ \\
\hline \multirow[t]{2}{*}{$\mathrm{t} \times$ Share of Firm tax } & $-0.039^{* *}$ & -0.003 & 0.003 & -0.013 \\
\hline & $(0.020)$ & $(0.022)$ & $(0.046)$ & $(0.056)$ \\
\hline \multirow[t]{2}{*}{ Log(land area) } & $-0.015^{*}$ & -0.056 & 0.008 & 0.070 \\
\hline & $(0.008)$ & $(0.064)$ & $(0.013)$ & $(0.072)$ \\
\hline \multirow[t]{2}{*}{ Log(population) } & 0.017 & $0.206^{* *}$ & -0.030 & -0.428 \\
\hline & $(0.011)$ & $(0.098)$ & $(0.024)$ & $(0.293)$ \\
\hline \multirow[t]{2}{*}{ Log(nonagri. population) } & $-0.035^{* *}$ & $0.103^{*}$ & 0.018 & 0.310 \\
\hline & $(0.016)$ & $(0.062)$ & $(0.030)$ & $(0.217)$ \\
\hline Splines of lagged $\log ($ tax reve.) & yes & yes & yes & yes \\
\hline Prefecture fixed effects & no & yes & no & yes \\
\hline R-squared & 0.1651 & 0.187 & 0.0245 & 0.025 \\
\hline $\mathrm{N}$ & 1432 & 1432 & 1432 & 1432 \\
\hline
\end{tabular}

Note: Robust standard errors, clustered at the prefecture level, are reported in parentheses.

* Significant at the $10 \%$ level; $* * 5 \%$; ** $1 \%$. 
Table 13: Estimates of long-run effects on industrial output growth

\begin{tabular}{lcc}
\hline Outcome var & \multicolumn{2}{c}{$\Delta \log ($ Industrial Output $)$} \\
\hline & $\frac{\text { Domestic }}{(1)}$ & $\frac{\text { Foreign \& HK etc. }}{(2)}$ \\
\hline$\Delta \log ($ taxreve $)$ & 0.136 & -0.695 \\
& $(0.291)$ & $(0.966)$ \\
$\Delta_{-1} \log ($ tax reve. $)$ & -0.090 & -0.348 \\
& $(0.158)$ & $(0.525)$ \\
R-squared & & \\
$\mathrm{N}$ & 0.0112 & 0.0009 \\
\hline
\end{tabular}

Note: Robust standard errors, clustered at the prefecture level, are reported

in parentheses. All specifications also control for the logs of population, nonagricultural population, total land area, the 5-piece splines of lagged tax

revenue, a linear time trend $t$, post $\times \mathrm{t}$, the interaction between $t$ and share of enterprise tax in 2001 and prefecture fixed effects.

* Significant at the $10 \%$ level; ** $5 \%$; *** $1 \%$. 


\section{A Appendix}

Table A.1 presents the summary statistics of our key variables using the whole sample.

Table A.2 reports the summary statistics for the major categories of government budgetary expenditures. 


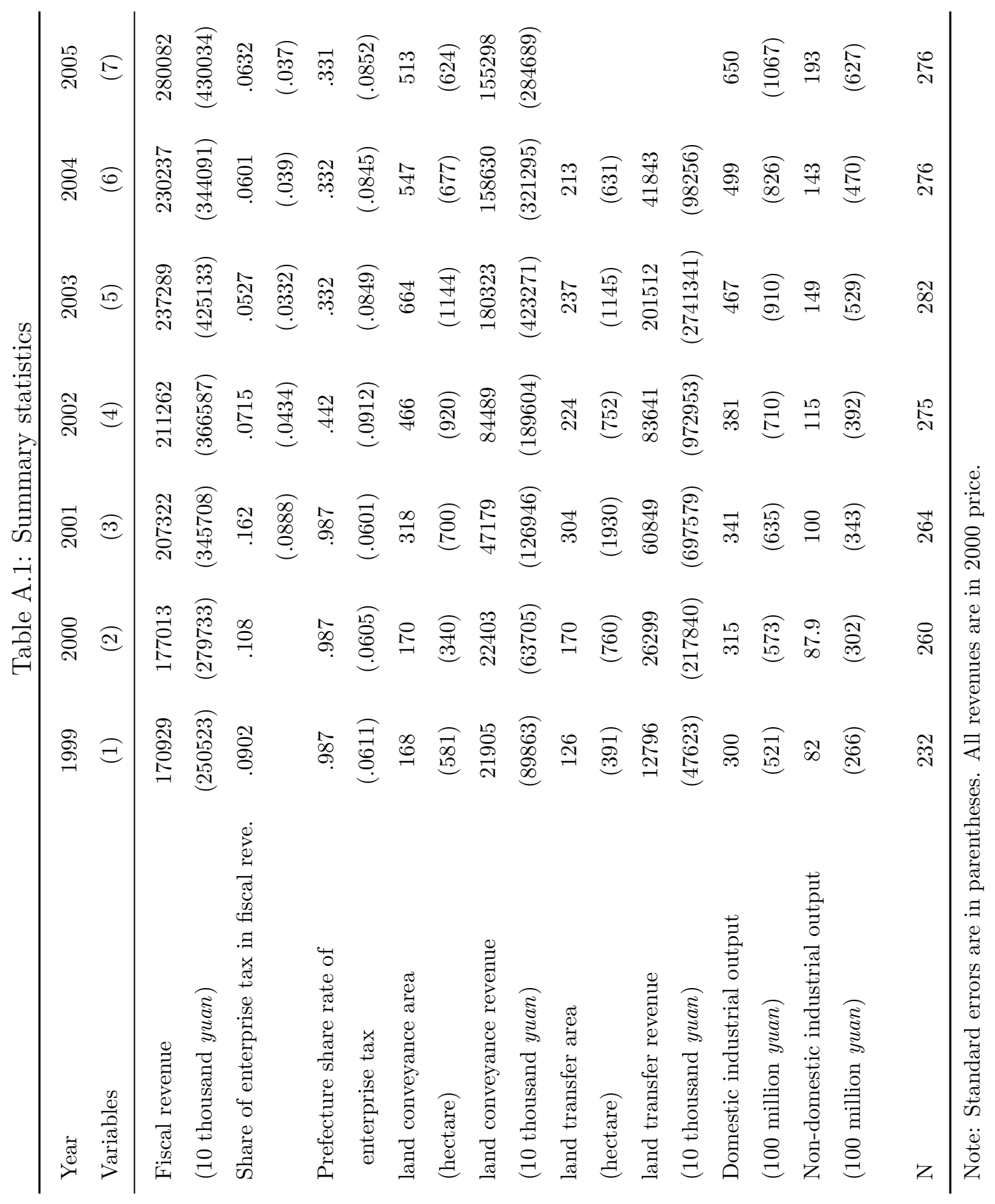




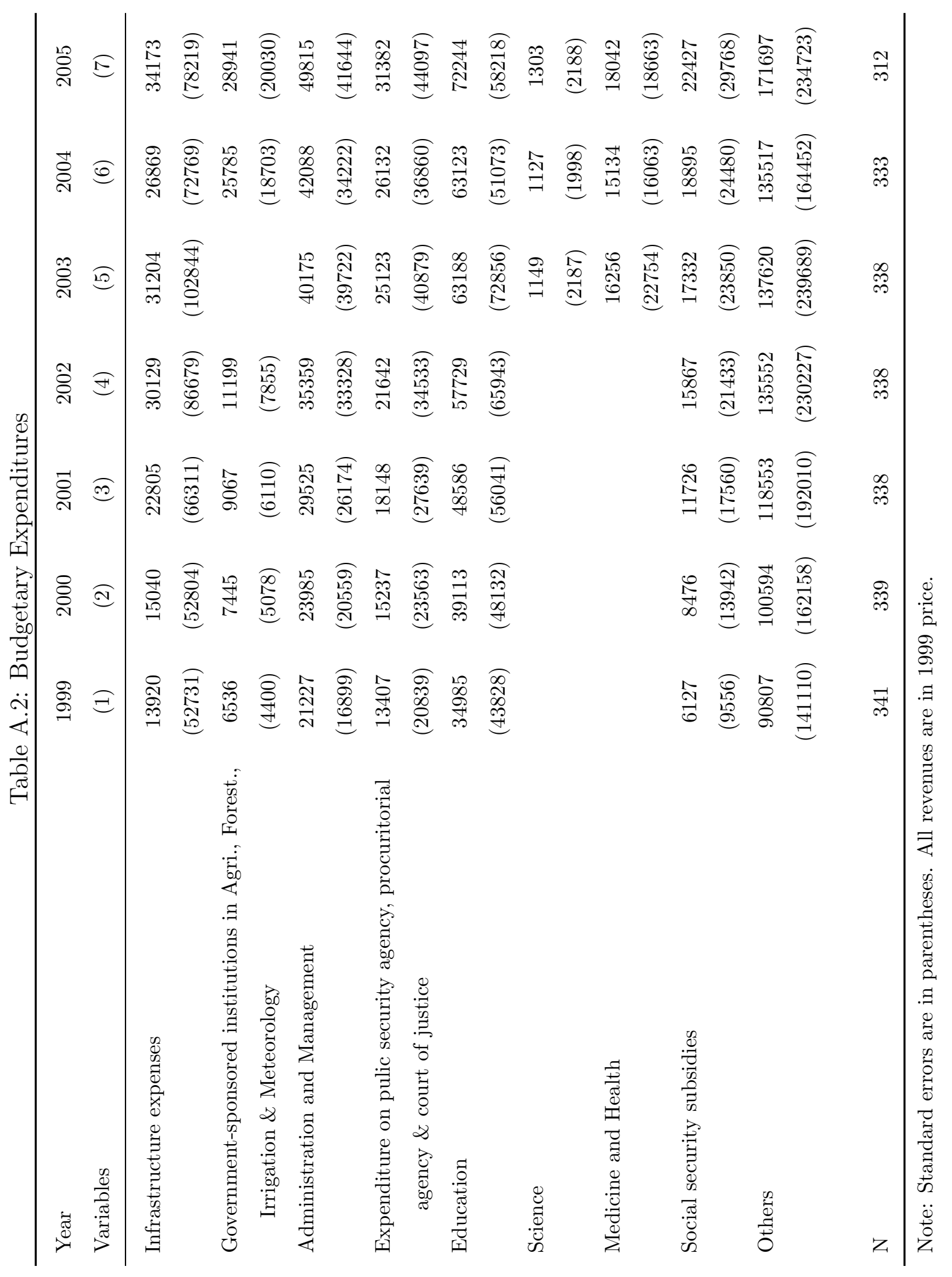

